\title{
REGION
}

The Journal of ERSA Powered by WU

Volume 2, Number 2, 2015, 1-26

DOI: $10.18335 /$ region.v2i2.43

journal homepage: region.ersa.org

\section{Regional quality of living in Europe}

\author{
Piet Lagas ${ }^{1}$, Frank van Dongen ${ }^{2}$, Frank van Rijn ${ }^{3}$, Hans Visser ${ }^{4}$ \\ ${ }^{1}$ PBL Netherlands Environmental Assessment Agency, The Hague, The Netherlands \\ (email: piet.lagas@pbl.nl) \\ 2 PBL Netherlands Environmental Assessment Agency, The Hague, The Netherlands \\ (email: frank.vandongen@pbl.nl) \\ ${ }^{3}$ PBL Netherlands Environmental Assessment Agency, The Hague, The Netherlands \\ (email: frank.vanrijn@pbl.nl) \\ ${ }^{4}$ PBL Netherlands Environmental Assessment Agency, The Hague, The Netherlands \\ (email: hans.visser@pbl.nl)
}

Received: 20 October 2014/Accepted: 25 May 2015

\begin{abstract}
This article sets out the conceptual framework and results of Regional Quality of Living indicators that were developed in order to benchmark European NUTS2 regions. Nine non-business-related indicators are constructed to support the goal of policy makers to improve the attractiveness of regions and cities for people or companies to settle in, and by doing so create economic growth. Each of the constructed indicators represents a pillar of the Quality of Living. The highest indicator scores are found for regions within Switzerland, Sweden, Norway and the Netherlands. Some countries show a wide divergence between regional scores. The southern regions of Italy and Spain, for example, have significantly lower scores than those in the north. In addition, capital city regions have better $R Q I$ scores. A positive correlation was found between the average $R Q I$ scores and both GDP per capita and weighted population density. Compared to GDP per capita, weighted population density has a modest influence on the RQI score. The European regions are divided into 11 clusters, based upon GDP per capita and weighted population density in order to benchmark a region with its peers.
\end{abstract}

\section{Introduction}

An ambition shared by all European countries is to create economic growth. In his book "Triumph of the city: How our greatest invention makes us richer, smarter, greener, healthier and happier" Glaeser (2011) focused on cities as important sources for economic growth and hot-spots of innovation. The Brookings Institution (Katz, Bradley 2013) and McKinsey's Global Institute (Dobbs et al. 2011) emphasized that cities and metropolitan regions are attractive places for people to settle and businesses to operate and are thus the engines for economic growth.

In order to create economic growth, the strengthening of competitiveness is essential; an important aspect of this competitiveness is the "quality of living". The Dutch government (IenM 2012) emphasizes the importance of strong regions with a good "quality of living" as well as good connections to the rest of Europe and the world.

Results from several studies have been published about the attractiveness of the Dutch regions for companies in terms of the economic environment (Raspe et al. 2010, Weterings et al. 2011). The Regional Competitiveness Index (Dijkstra et al. 2011, Annoni, Dijkstra 2013) shows the competitiveness of European regions. These studies mainly took economic 
factors into account, without including the "quality of living" factors for residents and employees. Although economic factors are important in determining the attractiveness of regions for companies, the quality of the (social, political, natural, etc.) environment for employees also plays an important role and therefore deserves attention. Currently, "quality of living" is not being monitored systematically.

A set of nine indicators characterizing the Regional Quality of Living Index $(R Q I)$ aims to fill this gap. These indicators provides a European-wide benchmark of nonbusiness-related indicators that are important to living standards and the quality of the human environment. This set of indicators offers the first comprehensive picture of the "quality of living" in almost all NUTS2 regions of the European continent, including all EU-countries and the non-EU-countries Norway and Switzerland.

Improvement of $R Q I$ scores may also contribute to achieving the objectives formulated in the Europe 2020 10-year strategy proposed by the European Commission on March 2010 (European Commission 2010) for the economic advancement of the European Union. The results can be used for other purposes as well: to improve the attractiveness of specific regions for students, or in the context of population decline.

A study of the "quality of living" in The Netherlands (Lagas et al. 2014) shows that Dutch regions are doing very well, and are comparable to the highest ranking European regions.

\section{Methods}

\subsection{Theory}

A review of the scientific literature on "quality of living" leads to the conclusion that, at present, there is no consensus on either the definition of the concept or specification of the underlying dimensions (Morais, Camanho 2011, van Kamp et al. 2003). Several terms and definitions are presented in the literature for concepts such as "quality of living", "quality of life", "liveability", and "standards of living". "Quality of living", as a concept, is attracting growing interest in the scientific literature. The subject has been picked up from different points of view by various institutes and researchers.

Regional Quality of Living (life) in the European Commission

In the European Union this topic gained more attention as it has become an essential element in the development of cities and regions. A European Parliament resolution (2005) on regional expansion indicates that these places are not only locations where problems are concentrated, but also where the future lies.

In 2008 the Commission on the Measurement of Economic Performance and Social Progress (CMEPSP) was created at the instigation of President Sarkozy of France because he was dissatisfied with the current level of statistical information about the state of the economy and society. The Commission's aim was to identify the limits of GDP as an indicator of economic performance and social progress. It was suggested that more attention should be given to "quality of life" as well as to Sustainable Development and the Environment (Stiglitz et al. 2009). Eurostat recently published new Quality of Life indicators for various countries in Europe (Eurostat 2015a).

Internationally, there are several indices that reflect "quality of living" or "liveability". Several research institutes or business consultants have considered this concept from various angles and at different levels of aggregation.

The Mercer Quality of Living index (Mercer 2010) and the Liveability index (EIU 2015) are used for determining the amount of compensation awarded to workers who temporarily have had to accept a lower standard of living. These indices and underlying indicators are intended for people working for companies in foreign countries. Other indices like International Living (2010) and NUMBEO (2012) focus on holiday and retirement situations. Another difference between several indices found in the literature is the level of analysis. Some international indices were published with a benchmark for countries (International Living 2010, OECD 2012a, EIU 2015). Country data, however, 
are not generally representative of regions because of the heterogeneity of countries. City indices are published by institutions, such as in the Quality of Living Index (Mercer 2010), the Economist Intelligence Unit's Liveability Index (EIU 2012) and Monocle's Most Liveable Cities index (Monocle 2011) for a limited number of cities.

Most of the indices mentioned and underlying data are commercially developed and not publicly available. At the moment there is no benchmark for European regions as concerns "quality of living" indices compiled from public data that are freely available.

\subsubsection{Quality of living characterized by 9 indicators}

Indicators and sub-indicators were chosen that are important for individuals, including their families, working at multinationals, as they may consider settling in a foreign region either for some time or permanently. After reviewing several indicators applied in the Quality of Living Index (Mercer 2010), Liveability Index (EIU 2012) and OECD Better Life Index (OECD 2012a), data was selected for 25 sub-indicators and nine indicators representing our RQI (Figure 1).

\subsubsection{NUTS 2 regions as level of analysis}

Using the Nomenclature of Territorial Units for Statistics (NUTS) for the journal European Regions, developed and regulated by the EU, the choice for the level of analysis was between NUTS0 regions (countries), NUTS1 regions (certain parts of countries), NUTS2 regions (provinces), and NUTS3 regions (city regions) or metropolitan regions (individual cities including smaller cities). The disadvantage of data at the national level is that these data are not representative of important regions within a country, as some countries are very heterogeneous. Italy, for example, where there is a wide divergence between the less developed south and the more developed north. The same applies to Turkey, Flemish and Walloon Belgium, former East and West Germany, and the southern and northern parts of Sweden, Finland and Norway.

Glaeser (2011) focuses on cities as important sources for economic growth, but for "quality of living" the surrounding area is important as well. For people living in cities, elements like Outdoor Recreation, Public Services (e.g. infrastructure around cities) and the Natural Environment are important factors for the Quality of Living. According to Hyslop (2013), metropolitan regions would be the preferred choice. This spatial level however isn't officially regulated by the EU and, consequently, available data are scarce.

Considering the relevance of the spatial level and data availability, data were collected for the European NUTS2 regions (NUTS2 codes 2010). This is in line with former research carried out by the PBL on Dutch top sectors and their European competitors (Raspe et al. 2012). NUTS2 is adopted as the spatial level of analysis by several other researchers, like the EU Regional Competitiveness Index (Dijkstra et al. 2011, Morais, Camanho 2011). In our study the non-EU member countries Norway and Switzerland were also taken into account because they are an integral part of the European economic system as members of the European Free Trade Association (EFTA).

\subsection{Methods of data handling}

The methods of data handling for creating the $R Q I$ were performed according to the OECD handbook on constructing composite indicators (Nardo, Saisana 2008). Data from reliable public sources like Eurostat, ESPON, Worldbank, OECD and several other sources (Lagas et al. 2014) are used in this study. Most of the data were available for the NUTS2 level. In other cases data available for NUTS0, NUTS1 or NUTS3 and City level were used to calculate regional indicator scores (Appendix A.2). Depending on the nature and availability of the data, imputations are carried out.

City data from several databases (e.g. Eurostat: Urban Audit - 418 'key cites') were used for the calculation of the regional sub-indicators. We made the assumption that the living conditions of the inhabitants of the largest cities are representative of the majority of the population of the region. When a region contained two or more cities a population weighted average value was calculated and considered as representative for the region. 


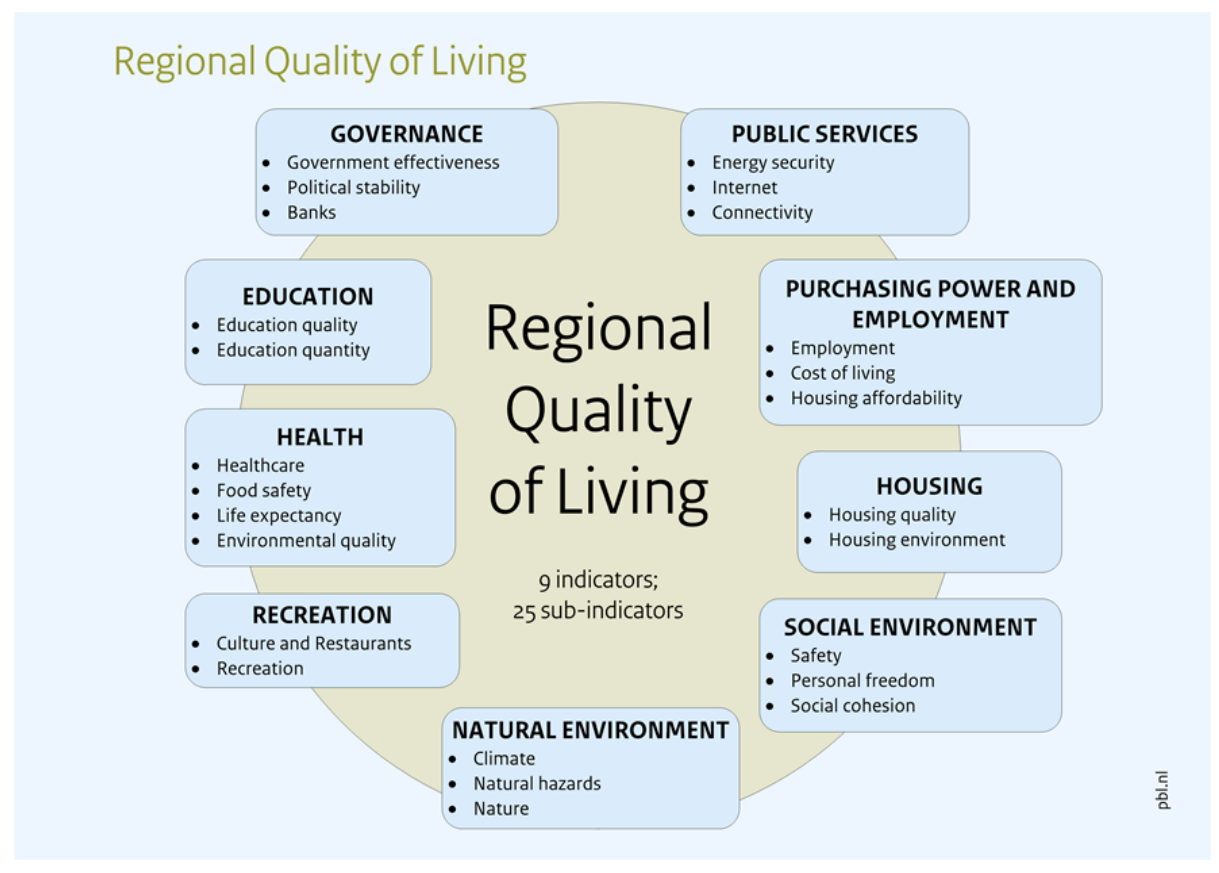

Figure 1: Indicators and sub-indicators to characterize the Quality of Living

Measurements of the indicators in the $R Q I$ were based preferably upon objective data, however we also used subjective data when objective regional data was unavailable.

\subsubsection{Calculation of indicators and sub-indicators}

Most of the indicators were calculated with at least two and up to seven underlying data sources (Appendix A.2). All sub-indicators and underlying data sources were scored using the Max-Min method: The score was normalized/scaled on the basis of the minimum and maximum score, resulting in a scoring between 1 and 10. For all indicators, a score of 10 represents the best and 1 the worst. Consequently, a low score does not automatically mean that the situation is bad or unacceptable, because only relative scores were calculated. Similarly, a high score does not necessarily mean a good or acceptable situation.

In some situations, outliers led to very high or very low average values of the data set or to a skewed distribution. When the average of the scaled data was lower than 4 or higher than 7, Winsorisation of the data was applied by taking the 95 percentile value as the maximum and/or the 5 percentile value as the minimum (Nardo, Saisana 2008).

When data were unreliable or unexplainable 'no data' (nd) were used. Expert judgement was applied to decide whether data were acceptable or not. For example, 'nd' was entered for the Spanish, Portuguese and French islands off the European continent and for some data sets for Iceland and non-EU countries, such as Turkey, Switzerland, Norway, Croatia, Liechtenstein and Macedonia. Most of the analyses were therefore performed for 305 NUTS2 regions.

Some regions are merged with surrounding ones to correct the bias resultant from commuting patterns. This was done for Wien (AT12+AT13), Greater London (UK11+UKl2+ UKH2+UKH3), Berlin (DE30 +DE40), Greater Amsterdam (NL23+NL32), Praha $(\mathrm{CZ01}+\mathrm{CZ} 02)$ and Brussels (BE10+BE24+BE31). The adopted merge criteria are based on the new harmonized EC-OECD definition of cities and commuting zones (OECD 2013). If a city and its commuting zone covers multiple regions, and more than forty percent of the population of a region lives inside that city and commuting zone, then these regions were combined (Annoni, Dijkstra 2013). 


\subsubsection{Merging national data and regional perception data}

When only objective data were available at the national scale and perception data available at the regional scale, we used these perception data for regional differentiation. The national average of the perception data for different regions inside a country was calculated. The deviation of this national average for a region was then used to calculate a regional value (Charron et al. 2012).

For example, the country sub-indicator A tells that Italy scored 7, while the regional sub-indicator B tells that the South Italian region scored 5 and the North Italian region scored 8 , and the country average for all regions is 7.4. Thus the results after considering two sub-indicators are that the North Italian region scored $7^{*}(8 / 7.4)=7,57$ and the South Italian region scored $7^{*}(5 / 7.4)=4.72$.

\subsubsection{Distance decay method}

The potential value scores were calculated for some sub-indicators by distance decay modeling and regional imputation (Equation 1). The values for $a$ and $b$ are estimated from empirical data. A matrix was developed for this purpose, containing the distances between all NUTS2 regions (316x316 matrix). For instance, we assumed that having a university within a distance of fifty kilometers gave a benefit of $60 \%$ and within a distance of one hundred kilometers a benefit of $10 \%$.

$$
P_{i}=\sum_{j=1}^{N} \frac{x_{j}}{1+\exp \left(a+b \ln \left(d_{i j}\right)\right)}
$$

where $P_{i}$ is the potential score of region $i, x_{j}$ is the number of universities in region $j$, and $d_{i j}$ is the distance between region $i$ and region $j$. The parameter $a$ controls the decay of the curve, $b$ the steepness of the curve.

\subsubsection{Weighting and sensitivity}

Although the primary aim of this study is to construct a set of indicators to monitor the "quality of living", we constructed the $R Q I$ to compare the overall performance of regions. The $R Q I$ value is calculated as the average of the nine quality of living indicators, using an equal weighting method. We deliberately chose not to apply a specific weighting scheme, because we consider all nine categories of the $R Q I$ as important pillars in the "quality of living". The process of assigning weights is subjective by nature, it generally depends on the objective of the index in question. Equal weighting schemes are often used in the literature for composite indicators. After testing several weighting methods equal weights were chosen in a recent study (Sharpe, Andrews 2012). The study concluded that all methods have advantages and shortcomings and that weighting can be influenced by personal valuations.

Furthermore, we do not expect that there is a causality between the indicators other than that they are possibly influenced by common underlying factors like the regional GDP per capita. An advantage of equal weights is that weights do not change when data are updated, which is a disadvantage of weighting methods using the Data Envelop Analysis such as in Benefit of the Doubt (Cherchye et al. 2006). Therefore for the determination of the $R Q I$ the average score of the nine quality of living indicators was calculated.

The Ordered Weighted Averaging method (Yager 1996) was used to check for compensability effects. The RQIOWA-max and a RQIOWA-min were calculated (Figure 2). RQIOWA-max is the result of a calculation when the best characteristics of a region are focused on by applying higher weighting factors to these indicators (Equation 2). A weighting of 9 for best scoring category; 8 for the second best and 1 for the worst scoring category. RQIOWA-min, in parallel fashion, uses the same calculation method where the worst indicator scores for a region are given the highest weights. This weighting scheme is based upon our decision that no indicator should weigh more than $20 \%$ and no less than $2 \%$ for the total Index. 


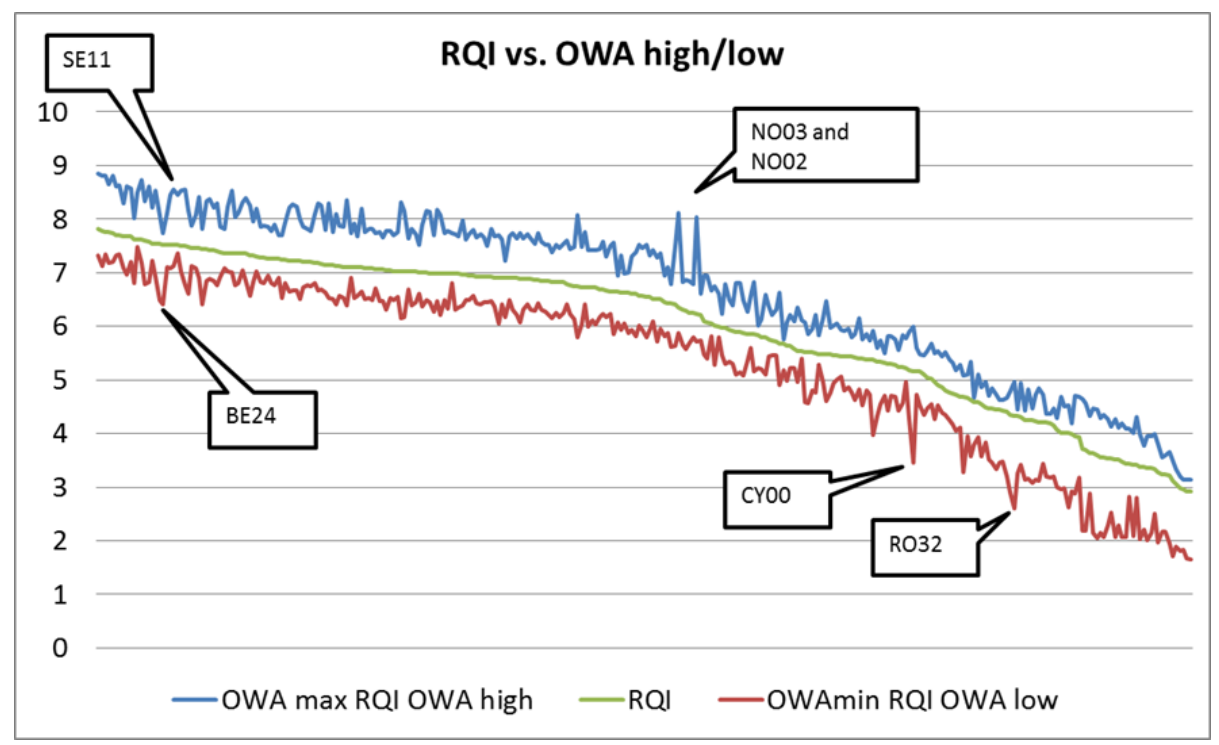

Note: Next to the RQI curve for 316 regions the corresponding RQIOWA-max and $R Q I O W A-\min$ score curve are shown (see Equation 2).

Figure 2: Analysis of compensability effects by determination of Regional Quality of Living applying the equal weighting method and the Ordered weighted Averaging method

$$
\operatorname{RQIOWA}\left(c_{1}, c_{2}, \ldots, c_{9}\right)=\frac{\sum_{i=1}^{9} c_{(i)} w_{i}}{\sum_{i=1}^{9} w_{i}}
$$

In this equation $c_{i}$ indicates the score for category $i, c_{(i)}$ the scores in the respective order. The $w_{i}$ are weighting factors, ranked from high to low. RQIOWA symbolizes the Ordered Weighted Averageing value for $R Q I$.

Figure 2 shows that the scores of NUTS2 regions will change when either the best characteristics of a region or its worst characteristics are made the focus.

The results show that for some regions a higher ranking will be realized with $R Q I O W A$ $\max$, but will realize a lower ranking with $R Q I O W A-m i n$, especially for some regions that have one extremely low score for one indicator (e.g. some Norwegion regions, shown in Figure 2). The opposite can be seen for regions with only one very good score (e.g. the Cyprus and Romanian region Bucaresti-Ilfov). For example, results for the regions of Bucuresti and Stockholm are thus:

RO32 Bucuresti-Ilfov: $R Q I O W A$-max, $R Q I, R Q I O W A$-min respectively: 4.9, 4.3, 2.6 with rankings: $227 ; 246 ; 256$.

SE01 Stockholm: RQIOWA-max, RQI, RQIOWA-min respectively: 8.6, 7.5, 7.1 rankings $12,13,12$.

\section{Results}

\subsection{Map of European regions}

On a map of the European regions (Figure 3) the highest values for the RQI can be seen in western Europe. A gradient from south to north and from east to west can be observed.

\subsection{Capital regions in European countries}

For most countries, the capital city region scored relatively higher than other regions in that country (Figure 4). Countries where their capital city region has extremely high 


\section{Regional Quality of living}

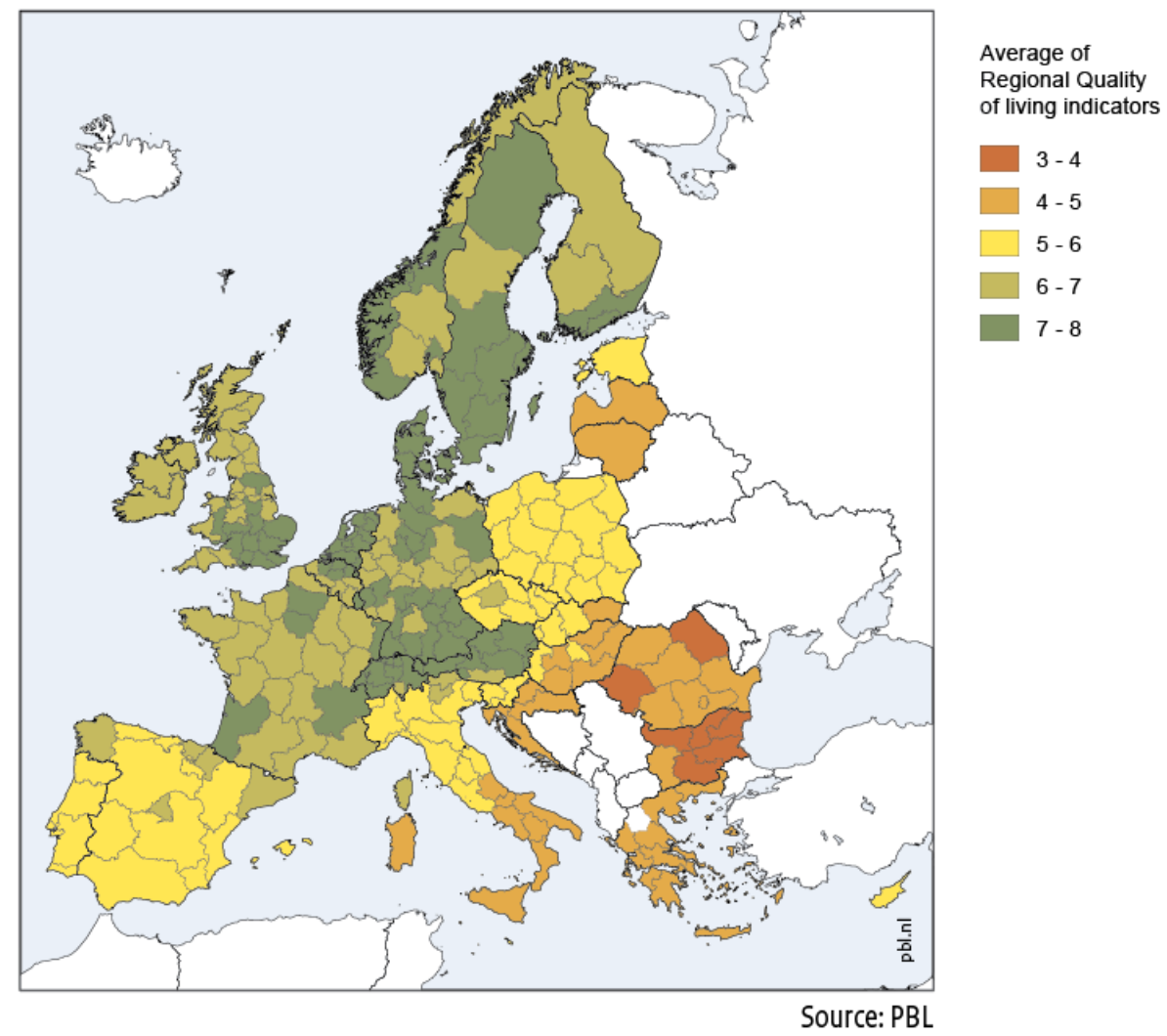

Figure 3: The Regional Quality of Living Index for European regions. Calculated as the average score of nine $R Q I$ indicators, each scaled 1 to 10

$R Q I$ scores are Norway (Oslo region), France (Paris, Iles de France region), Ireland (Dublin region), Czech (Prague region), Slovakia (Bratislava region) and Bulgaria (Sofia region, Yugozapaden region). This is in line with the statement of Glaeser (2011) that metropolitan city regions are important sources for economic growth and should therefore hold a better "quality of living". The regions that include the capital city are mostly large with relatively high GDP and high population densities with consequently relatively high values for $R Q I$ categories Education, Public Services and Recreation. Large variation within countries is found for Italy (IT), Belgium (BE) and Spain (ES). The northern regions of both these countries score better in terms of the RQI than their southern counterparts. Also, large variations are found in France (FR), Germany (DE) and Norway (NO). Figure 5 shows a large gap between average scores for northwestern European countries (average $R Q I>6.8$ ) and south-eastern countries of Europe (average $R Q I<5.8$ ).

\subsection{RQI vs GDP per capita and weighted population density}

\subsubsection{Regional GDP per capita vs Regional Quality of Living}

Higher GDP per capita mostly relates with a better $R Q I$. Below a GDP per capita of about 18.000 euros no $R Q I$ scores higher than 6 were found (Figure 5). Probably there is some kind of threshold value that should be reached, after which the RQI score improves remarkably. An explanation could be that regions with a less developed economy primarily focus on the development of the basic needs, like infrastructure (Public services), basic Education and Health care services and after that the focus is on other categories of $R Q I$ 
RQI - Regional Quality of Living Index of the European regions

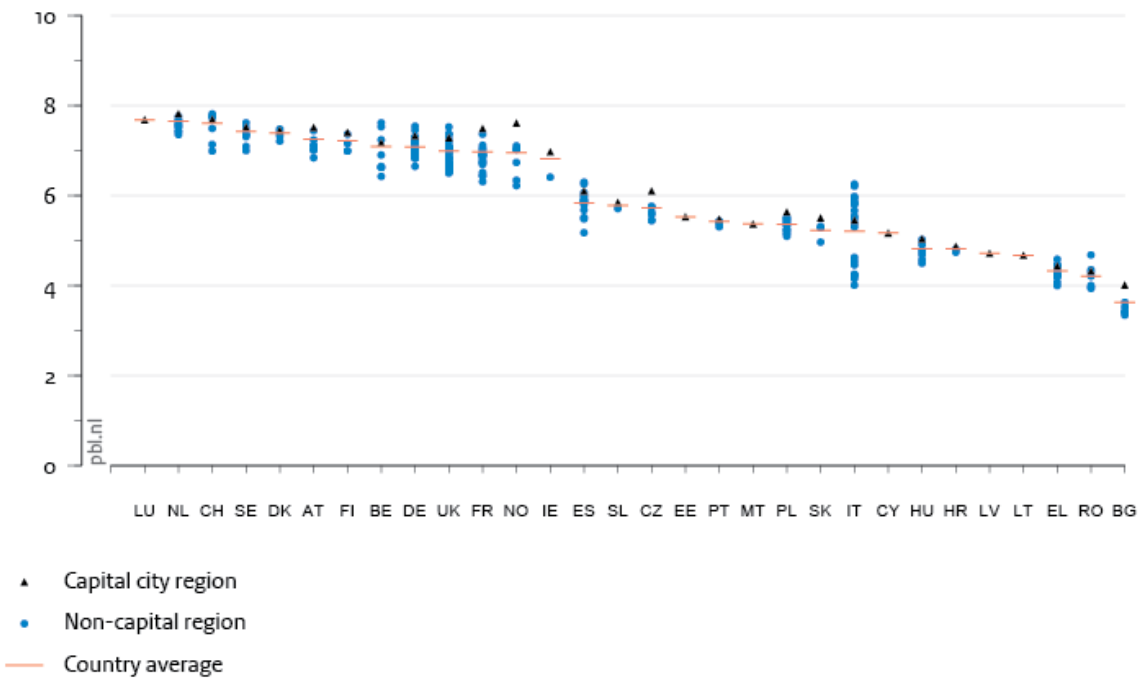

Figure 4: $R Q I$ values for the European NUTS2 regions, showing the average $R Q I$ value per country and its capital city

like Housing, Recreation, Social Environment and (higher) Education.

Between GDP and $R Q I$ a strong correlation of 0.78 was found. The scores for Governance, Social Environment, Education, Public Services and Recreation are strongly related to GDP (see also Table 1). However, a negative relation is found for Natural Environment.

\subsubsection{Population density vs Regional Quality of Living}

The influence of population density on the $R Q I$ score is analyzed because it is suspected to have a positive correlation with amenity-based $R Q I$ categories like Education and Public Services resulting in higher scores on the $R Q I$. The conventional definition of population density is population/area for NUTS2 regions This definition is problematic because the ratio between the urban and rural environment shows large variations. This results in a very low population density for regions with a million-person city situated in a very large rural area. In comparison with the relevant part of a NUTS2 region, where the people live, the population density is much higher. Therefore a weighted population density $(w P D)$ will be more useful to analyze the relations between densities and the $R Q I$. The $w P D$ was calculated as the average of two overlapping $10 \times 10 \mathrm{~km} 2$ grids with grid population as a weighting factor.

A relatively weak but significant correlation of 0.10 is found between $\log w P D$ and $R Q I$. A closer look (Figure 6) shows that a higher $w P D$ indeed relates with a higher score on the $R Q I$ in general but that no increase is seen above $\log w P D$ values of $3.0-3.2$ (1000 - 1600 Inhabitants/km2). High weighted population density may lead to better scores for Education, Public Services and Recreation but it seems that above a certain population density no further improvement will be realized.

\subsubsection{Clustering regions with GDP per capita and weighted population density}

To identify the peers for the European regions, a cluster analysis was conducted based on GDP per capita and $w P D$. As a result, clusters regions can be compared with other regions with comparable GDP per capita and $w P D$. Figure 7 shows the European regions with their logarithmic values of GDP per capita and $w P D$ and the eleven clusters that were chosen. For both GDP per capita and $w P D$ four classes were concerned: high, 


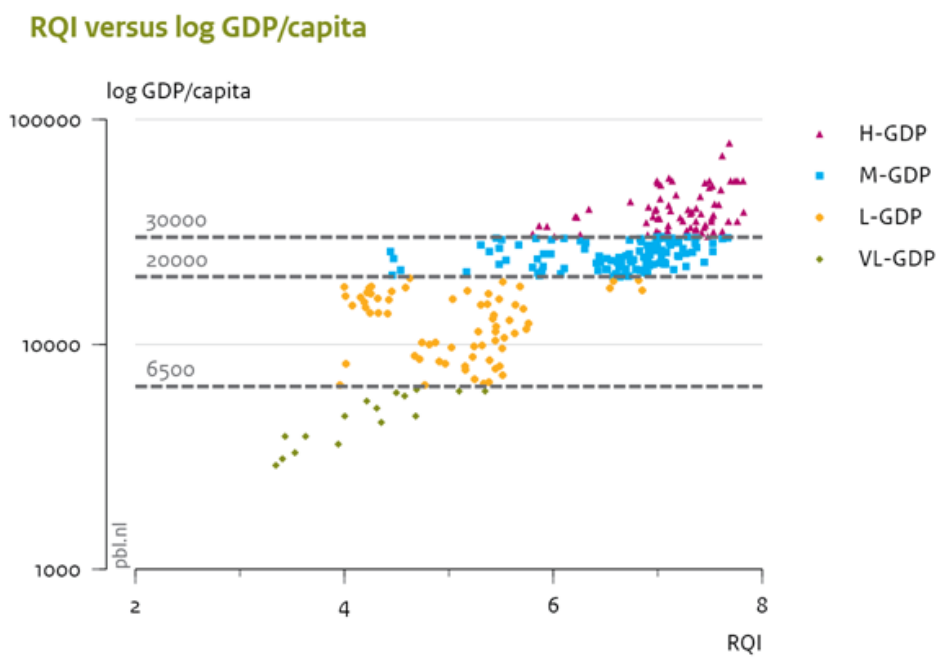

Figure 5: Average score of Regional Quality of Living Indicators vs several classes of regional GDP per capita

RQI relation with Weighted population density

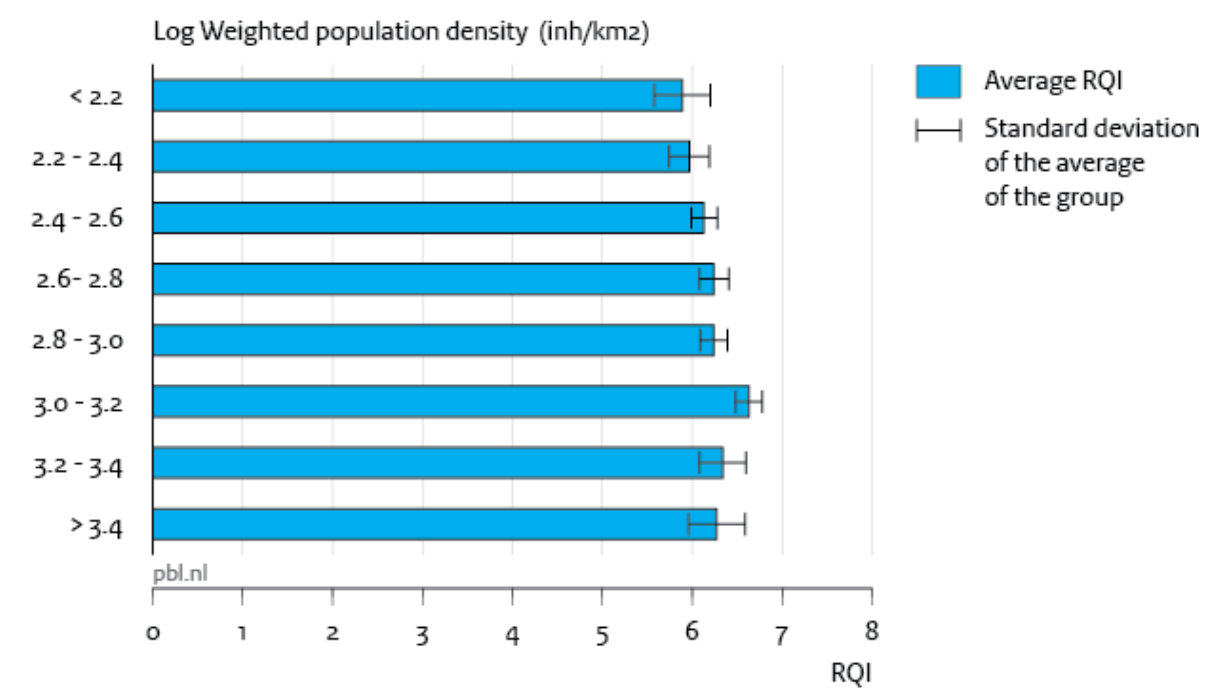

Figure 6: Average scores for Regional Quality of Living indicators for different levels of weighted population density 


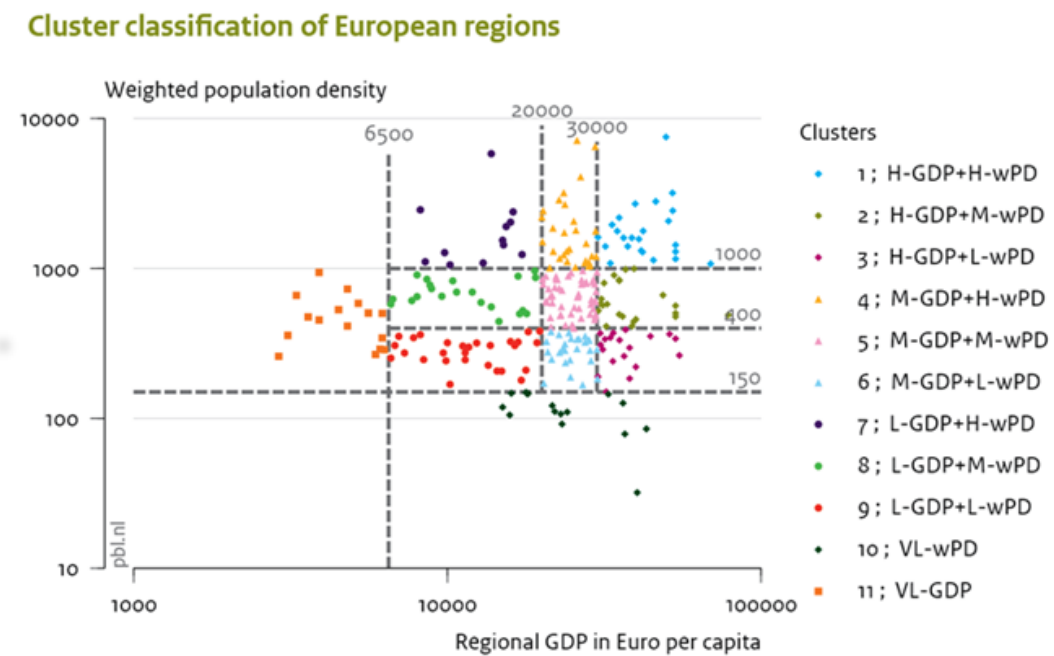

Figure 7: The 11 clusters of regions of Europe classified with their GDP per capita and population density

moderate, low and very low (See also for European maps in Appendix Figure A.1a and A.1b). The highest values for $R Q I$ are found for Cluster 1 High GDP per capita and high $w P D(\mathrm{H}-\mathrm{GDP}+\mathrm{H}-\mathrm{wPD})$. The highest average $R Q I$ values are found for the clusters with high GDP (Figure 8). The influence of $w P D$ is different for different GDP per capita ranges.

\subsection{Clustering of the European regions}

Table 1 shows the average scores for the nine $R Q I$ indicators for the eleven clusters. These data make it is possible to compare a region with the average scores of all regions in the same cluster in order to identify strong and weak indicators. In Appendix A.3 the regions of the different clusters are presented with their $R Q I$ scores and the lowest and highest indicator scores per region.

\subsubsection{Regions with high GDP per capita}

The highest $R Q I$ scores are found for Swiss and Dutch regions in the clusters with high or moderate $w P D$. In the cluster with low $w P D$ Swedish and Danish regions are scoring high.

Italian regions show the lowest scores. In all three clusters regions in the southern parts of Europe like Italy and Spain show relatively low $R Q I$ scores. Table A.2 shows that the differences between the three clusters with regard to $w P D$ can be found in Education and Recreation and in the other direction for Natural Environment and Social Environment. The regions with the highest $w P D$ (Hamburg 3200 inhabitants/ km2), Ile de France $(7500$ inh/ km2) and Greater London (2700 inh/ km2) have relative lower $R Q I$ values. These results are in line with the findings by the OECD (2006). They concluded that moderate sized cities showed higher productivity than the largest metropoles worldwide. Though most of the largest metropoles have higher economic growth, foreign investment and labour productivity than the rest of the country, they are also more polluted, crime-ridden and socially disparate (OECD 2006).

\subsubsection{Regions with moderate GDP per capita}

English and Dutch regions score relatively high in comparison to their peers in the clusters with moderate GDP per capita (see Table A.3). High scores are also found for several French, German and Belgian regions. The biggest cluster with moderate $w P D$ 
Average RQI for 11 clusters of European NUTS2 regions

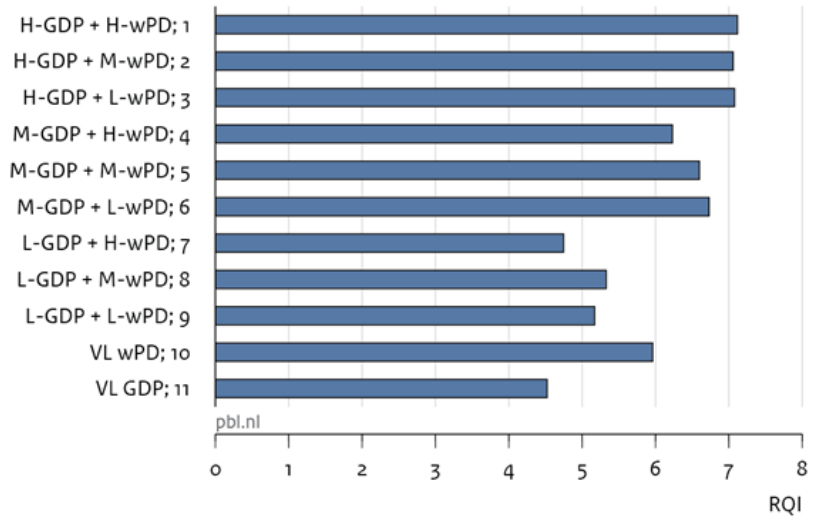

Figure 8: Average $R Q I$ values for the European Nuts2 regions for 11 clusters

involves several western European regions of The Netherlands, France, Germany and the United Kingdom which have scores higher than 7. In the cluster with low $w P D$, Austrian, French and English regions, have the highest scores of 6.7 to 7.5. The regions with the highest $w P D$, West Midlands (3200 inh/ km2), Merseyside, (2200 inh/ km2) and Greater Manchester (2700 inh/ km2), have relatively low $R Q I$ values. Table 1 shows that the differences between the three clusters with regard to $w P D$ can be found in Education and in the other direction for Natural Environment and Purchasing Power and Jobs.

\subsubsection{Regions with low GDP per capita}

English, Czech and Polish regions have the highest rankings in the clusters with low GDP per capita (see Table A.4). Differences as a consequence from different $w P D$ are significant. In the cluster with high $w P D$ the Mazowieckie region has the highest score of 5.64 while in the clusters with moderate and low $w P D$ the best score is 6.8 . In the cluster with moderate and low $w P D$ the English regions score best. Only for Health can a pattern be recognized that shows that lower population density leads to better scores.

\subsubsection{Regions with very low GDP per capita or population density}

The cluster with low $w P D$ shows high scores for the Austrian region, Burgenland, and some Scandinavian regions. Relatively few people are living in these regions (see Table A.5).

In the cluster with very low GDP East European regions are found. From these regions Polish regions have the highest rankings (see Table A.5).

\subsubsection{Regional benchmarking with peers}

Figure 9 shows for the Dutch region of Utrecht a comparison with the characteristics of Cluster 1 (high-GDP per capita and high-wPD) and the average score of all European regions. Utrecht scores high on Education, Governance, Social Environment and Recreation, even better than the average of Cluster 1 regions, but low on Natural Environment compared to the average of all regions as well as the average of the Cluster 1 regions. In comparison to its peers the Bucaresti-Ilfov region shows high scores on Purchasing Power and Employment and Natural Environment but low on Governance, Social Environment, Health, and Recreation. 
Table 1: Characteristics of the 11 clusters of European NUTS2-regions

\begin{tabular}{|c|c|c|c|c|c|c|c|c|c|c|}
\hline Cluster & $\begin{array}{l}\text { Gover- } \\
\text { nance }\end{array}$ & PP\&E & $\begin{array}{l}\text { Social } \\
\text { environ- } \\
\text { ment }\end{array}$ & Health & $\begin{array}{l}\text { Educa- } \\
\text { tion }\end{array}$ & $\begin{array}{l}\text { Public } \\
\text { services }\end{array}$ & $\begin{array}{l}\text { Recrea- } \\
\text { tion }\end{array}$ & $\begin{array}{l}\text { Natural } \\
\text { environ- } \\
\text { ment }\end{array}$ & Housing & $\begin{array}{l}\text { Average } \\
\text { of RQI }\end{array}$ \\
\hline H-GDP H-wPD & 7.9 & 6.5 & 8.4 & 7.5 & 7.8 & 7.6 & 7.3 & 5.0 & 6.1 & 7.1 \\
\hline H-GDP M-wPD & 8.0 & 6.6 & 8.5 & 7.5 & 7.3 & 7.5 & 6.8 & 5.5 & 5.9 & 7.1 \\
\hline H-GDP L-wPD & 8.7 & 6.6 & 8.9 & 7.8 & 6.3 & 7.2 & 6.7 & 6.0 & 5.7 & 7.1 \\
\hline M-GDP H-wPD & 6.7 & 5.4 & 7.4 & 6.9 & 6.4 & 6.4 & 6.5 & 5.0 & 5.3 & 6.2 \\
\hline M-GDP M-wPD & 7.3 & 5.9 & 8.0 & 7.5 & 6.1 & 6.9 & 6.6 & 5.5 & 5.6 & 6.6 \\
\hline M-GDP L-wPD & 7.6 & 6.3 & 8.0 & 7.6 & 5.4 & 7.1 & 6.8 & 6.3 & 5.6 & 6.7 \\
\hline L-GDP H-wPD & 4.4 & 6.4 & 4.6 & 4.5 & 3.5 & 4.9 & 3.7 & 6.3 & 4.3 & 4.7 \\
\hline L-GDP M-wPD & 5.7 & 5.6 & 6.3 & 5.4 & 4.2 & 5.2 & 4.7 & 6.4 & 4.4 & 5.3 \\
\hline L-GDP L-wPD & 5.4 & 5.4 & 5.9 & 5.8 & 3.6 & 5.2 & 4.4 & 6.3 & 4.6 & 5.2 \\
\hline VL wPD & 6.9 & 5.7 & 7.5 & 7.3 & 3.9 & 5.6 & 5.2 & 6.4 & 5.2 & 6.0 \\
\hline VL GDP & 4.3 & 6.2 & 5.0 & 3.5 & 2.6 & 4.7 & 3.7 & 7.1 & 3.5 & 4.5 \\
\hline
\end{tabular}

Note: PP\&E ... Purchasing Power and Employment

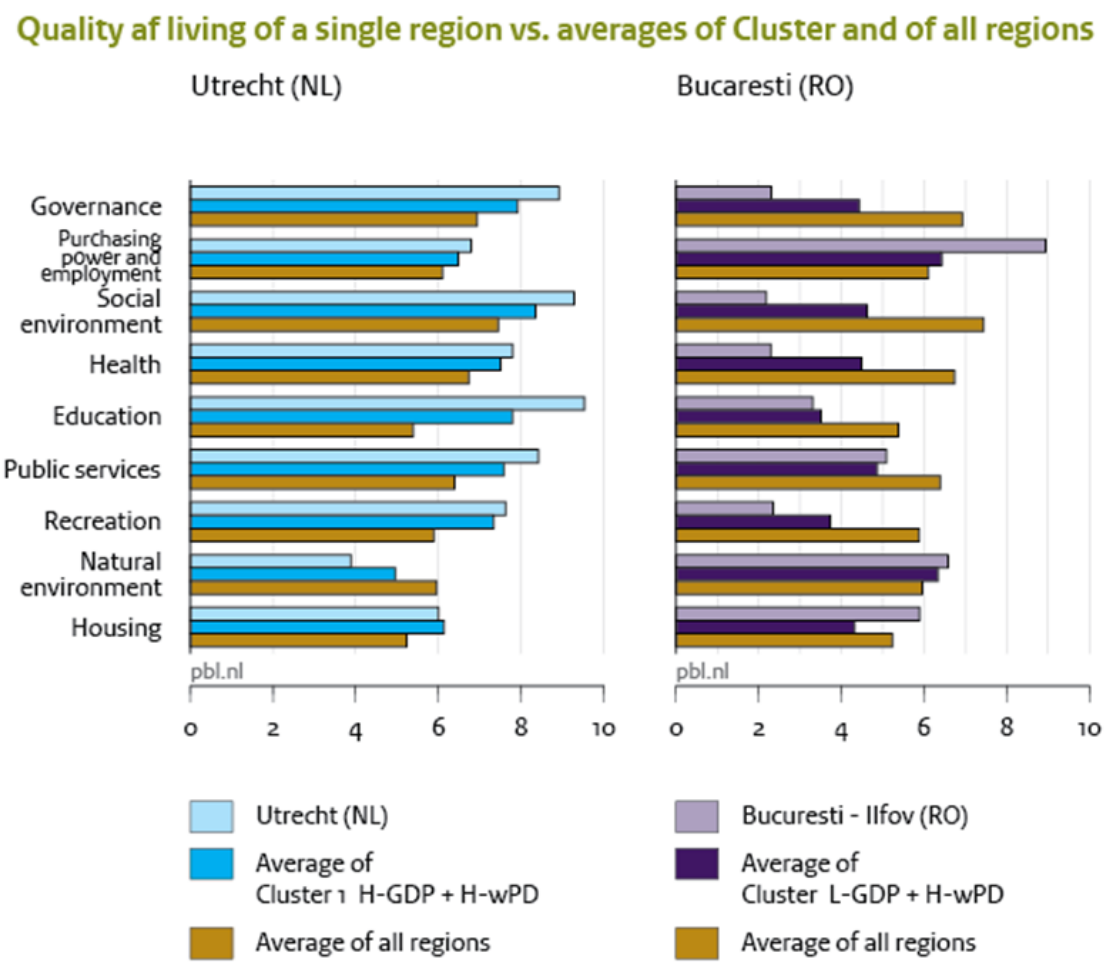

Figure 9: Examples of benchmarking European regions with their peers 


\section{Conclusions}

The Regional Quality of Living Indicators, using non-business-related indicators, can help to improve the attractiveness of regions, thereby encouraging people and companies to settle and invest in these regions. A set of nine indicators is presented. The highest scores for $R Q I$ indicators are found for regions in Switzerland, Sweden, Norway and the Netherlands.

Some countries show a wide divergence between regional scores. The southern regions of Italy and Spain, for example, have significantly lower scores than those in the north. In addition, most of the capital city regions have a high $R Q I$ value in comparison to the rest of their country.

Results show a relation between $R Q I$ scores and the GDP per capita and population density. Significant correlation is found between $R Q I$ and GDP per capita. Between population density and $R Q I$ scores a relatively weak but also significant positive correlation is found. In order to benchmark a European region with its peers, a cluster analysis was conducted based on GDP per capita and weighted population density. Eleven different clusters are distinguished, which makes benchmarking between comparable regions possible to identify strong or weak $R Q I$ characteristics of a region.

Improving the "quality of living" can help to make the regions and their cities more attractive for local residents and businesses, but also to attract foreign knowledge workers and multinationals. It may help countries and regions in Europe to realize their ambitions to create economic growth and to achieve the objectives formulated in the Europe 2020 10-year strategy presented by the European Commission on March 2010 (European Commission 2010) for advancement of the economy of the European Union. 


\section{References}

Annoni P, Dijkstra L (2013) EU regional competitiveness index (RCI 2013). Joint Research Center of the European Commission, report EUR 26060 EN, Brussels

Charron N, Lapuente V, Dijkstra L (2012) Regional governance matters: A study on regional variation in quality of government within the EU. European Commission, DG Regional Policy, WP 01/2012

Cherchye L, Moesen W, Rogge N, van Puyenbroek T (2006) An introduction to 'benefit of the doubt' composite indicators. Social Indicators Research 82: 111-145. CrossRef.

CIRI - The Cingranelli and Richards Human Rights Data Project (2012) The Cingranelli and Richards Human Rights Data Project. http://www.humanrights.com

DG Regional Policy (2010) Measuring quality of government and sub-national variation. Report for the EU Commission of Regional Development, European Commission, DG Regional Policy, Policy Development Directorate

Dijkstra L, Annoni P, Kozovska K (2011) A new regional competitiveness index: Theory, methods and findings. European Commission, DG Regional Policy, WP 2/2011

Dobbs R, Smit S, Remes J, Manyika J, Roxburgh C, Restrepo A (2011) Urban world: Mapping the economic power of cities. http://www.mckinsey.com/insights/ urbanization/urban_world, McKinsey institute

EIU - Economic Intelligence Unit (2012) Global food security index. http:// foodsecurityindex.eiu.com/

EIU - Economic Intelligence Unit (2015) Global liveability ranking. http://www.eiu . com/public/topical_report.aspx?campaignid=Liveability2014

ESPON (2011) Territorial dynamics in Europe: Trends in accessibility. http: //www.espon.eu/main/Menu_Publications/Menu_TerritorialObservations/ trendsinaccessibility.html

ESPON (2013) Territorial Dynamics in Europe: Natural hazards and climate change in European regions. Territorial observation no. 7, http://www.espon.eu/main/Menu_ Publications/Menu_TerritorialObservations/T07_June2013.html

ESS - European Social Survey (2014) European Social Survey, open ESS round 6. http:// nesstar.ess.nsd.uib.no/webview/velocity?v=2\&mode=documentation\&submode= abstract\&study=http://129.177.90.83:80/obj/fStudy/ESS6e02.1

Eurofound (2014) European quality of life survey, 2011-2012. https: //www. eurofound.europa.eu/news/spotlight-on/quality-of-life/ overview-quality-of-life-citizens-and-public-services

European Commission (2010) Europe 2020: Commission proposes new economic strategy in Europe. http://europa.eu/rapid/press-release_IP-10-225_en.htm

Eurostat (2015a) Eurostat database. http://ec.europa.eu/eurostat/data/database

Eurostat (2015b) Landscape diversity expressed as Shannon Evenness Index. http://ec.europa.eu/eurostat/statistics-explained/index.php/File: Landscape_diversity_expressed_as_Shannon_Evenness_Index,_by_NUTS_2_ regions,_2009.PNG

Glaeser E (2011) Triumph of the city: How our greatest invention makes us richer, smarter, greener, healthier and happier. MacMillan, New York

Hyslop D (2013) Global peace indicator. Personal communication, 6 February 2013, Institute for Economics and Peace, Sydney, Australia 
IenM - Ministry of infrastructure and environment (2012) Planning vision for infrastructure and landscape. Dutch ministry of infrastructure and the environment, The Hague

International Living (2010) 2010 Quality of Life Index: 194 countries ranked and rated to reveal the best places to live. http://internationalliving.com/publications/ reports/quality-of-life-report/

Katz B, Bradley J (2013) The metropolitan revolution. http://metrorevolution.org/, Brookings Institution

Lagas P, Kuiper R, van Dongen F, van Rijn F, van Amsterdam H (2014) Regional quality of living in Europe. Report nr 1271, PBL Netherlands Environmental Assessment Agency. http://www.pbl.nl/sites/default/files/cms/publicaties/ PBL-2014-Regional-Quality-of-Living-in-Europe-1271_0.pdf

Mercer (2010) Defining quality of living. http://web.archive.org/web/ 20110705043507/http://www. mercer. com/referencecontent.htm?idContent= 1380465

Michelin (2013) Michelin-starred restaurants - the Michelin Guide selection. http: //www.viamichelin.com/web/Restaurants

Monocle (2011) Most liveable cities index. http://monocle.com/magazine/issues/45/ thelliveable-cities-index-2011/

Morais P, Camanho AS (2011) Evaluation of performance of European cities with the aim to promote quality of life improvements. Omega 39: 398-409. CrossRef.

Nardo M, Saisana M (2008) OECD/JRC Handbook on constructing composite indicators. Putting theory into practice. European Commission, Joint Research Centre. https: //composite-indicators.jrc.ec.europa.eu/?q=content/oecd-jrc-handbook

NCIS - National Center for Education Statistics (2012) Programme for international student assessment (PISA). OECD

NUMBEO (2012) Cost of Living. http://www. numbeo.com

OECD (2006) OECD territorial reviews: Competitive cities in the global economy. OECD Publishing, Paris

OECD (2011) Sustainable Governance Indicators. OECD. http://www.sgi-network . de/, OECD, Bertelsmann Stiftung

OECD (2012a) Better Life Index. http://www.oecdbetterlifeindex.org/

OECD (2012b) OECD health statistics. http://www.oecd.org/els/health-systems/ health-data.htm

OECD (2013) Definition of functional urban areas (fua) for the OECD metropolitan database. http://www.oecd.org/gov/regional-policy/ Definition-of-Functional-Urban-Areas-for-the-OECD-metropolitan-database . pdf

QS - QS topuniversities (2013) World university rankings; ranking of universities of Europe. http://www.topuniversities.com/

Raspe O, Weterings A, Thissen M (2012) De internationale concurrentiepositie van de topsectoren. PBL report number 500210003, PBL Netherlands Environmental Assessment Agency, The Hague

Raspe O, Weterings A, van Oort F (2010) De economische kracht van de Noordvleugel van de Randstad. OECD publishing, SBN nr 9264027092 November 2006, PBL Netherlands Environmental Assessment Agency, The Hague 
Sharpe A, Andrews B (2012) An assessment of weighting methodologies for composite indicators: The case of the index of economic well-being. http://www.csls.ca/ reports/csls2012-10.pdf, Centre of Study of Living Standards

S\&P - Standard and Poor (2014) Standard and Poor ratings. http://www . tradingeconomics.com/country-list/rating

Stiglitz J, Sen A, Fitoussi J (2009) Report by the commission on the measurement of economic performance and social progress. http://www.stiglitz-sen-fitoussi.fr/ documents/rapport_anglais.pdf

TI - Transparency International (2012) Global corruption barometer. http://www . transparency.org/

van Kamp I, Leidelmeijer K, Marsman G, De Hollander A (2003) Urban environmental quality and human well-being. towards a conceptual framework and demarcation of concepts; a literature study. Landscape and Urban Planning 65: 5-18. CrossRef.

VoH - Vision of Humanity (2012) Global peace index. http://www . visionofhumanity . org

WEF - World Economic Forum (2013) Eu28 -- analysis of EAPI performance. http:// reports. weforum .org/global-energy-architecture-performance-index-2014/ eu28-analysis-of-eapi-performance/

Weterings A, Raspe O, van den Berge M (2011) The European landscape of knowledge-intensive foreign-owned firms and the attractiveness of Dutch regions. PBL Netherlands Environmental Assessment Agency, The Hague. http://www.pbl.nl/sites/default/files/cms/publicaties/002823_ european_landscape_knowledgeintensive_firms.pdf

WHO (2011) Global health observatory data. http://www . who.int/gho/database/en/

Wikipedia (2014) List of International schools 2014. http://en.wikipedia.org/wiki/ List_of_international_schools

Worldbank (2012) World governance indicators. http://www.govindicators.org

Yager R (1996) Quantifier guided aggregating using owa operators. International Journal of Intelligent Systems 11: 49-73. CrossRef. 


\section{A Appendix}

\section{A.1 Maps of Europe for different clusters}

Figure A.1a and A.1b shows the different classes for GDP/cap and population density. European regions are classified: high, moderate, low and very low. Figure A.2 shows the map of Europe for 11 clusters. All the 11 clusters are given with their NUTS 2 regions in different tables with regard to their GDP per capita in Table A.2 to A.5.

\section{GDPcategory (4 categories)}

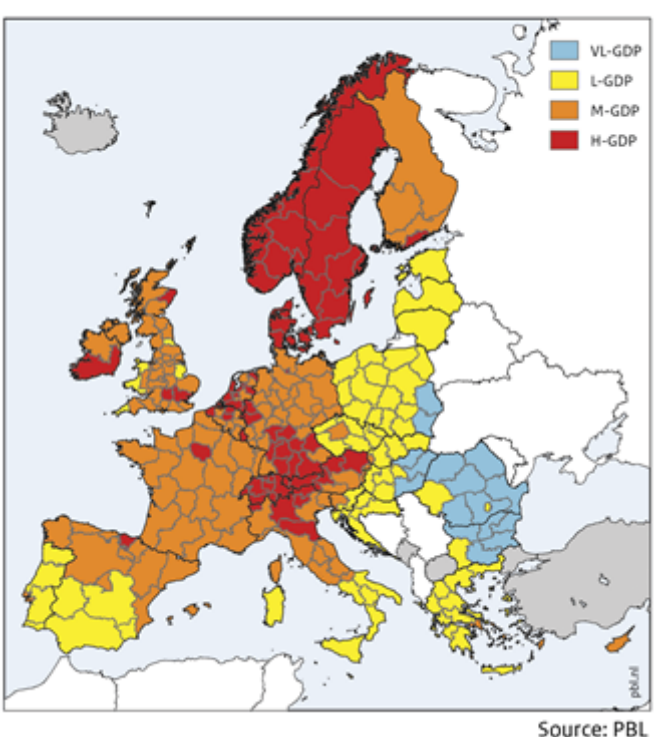

(a) Overview of categories with respect to GDP per capita in the European region. (euro/inhabitant); $1=$ High $>30000 ; 2=$ Moderate $(20000-30000) ; 3=$ Low (6500-20000); $4=$ very low $(<6500)$

\section{Weighted population density (4 categories)}

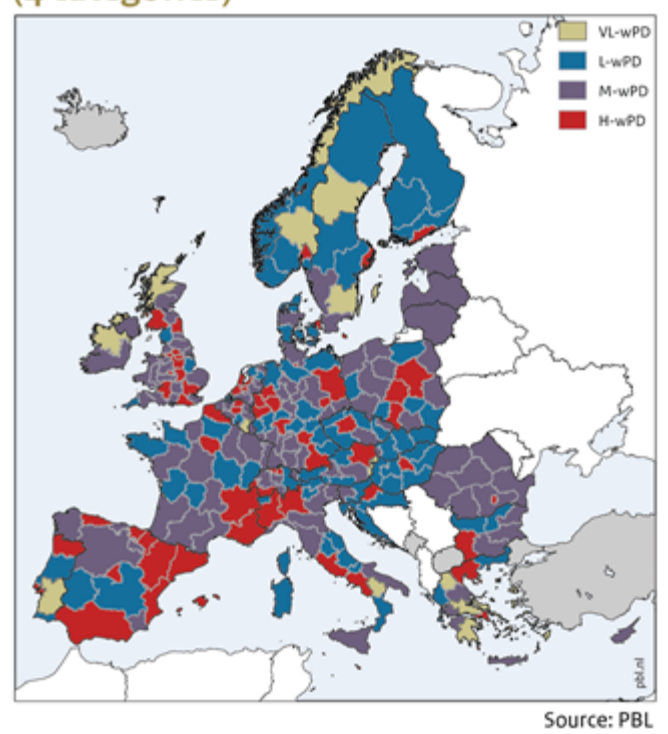

(b) Overview of categories with respect to weighted population density $\left(\mathrm{inh} / \mathrm{km}^{2}\right)$ in the European regions $1=$ High $>1000 ; 2=$ Moderate $(400-1000)$; $3=$ Low $(150-400) ; 4=$ very low $(<150)$

Figure A.1: Categories of regions 


\section{Clusters of NUTS2 regions in Europe (11 clusters)}

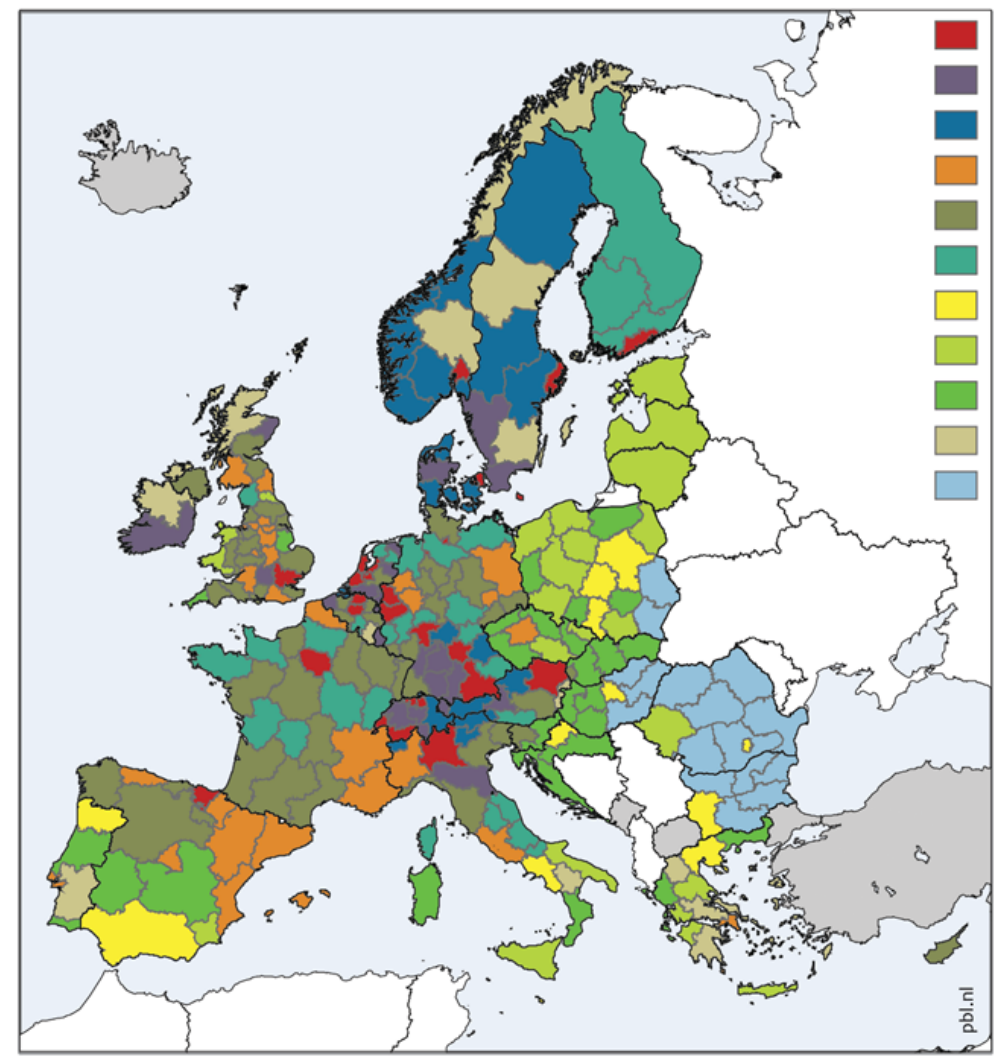

1: H-GDP + H-WPD

2: H-GDP + M-WPD

3: H-GDP + L-WPD

4: $M-G D P+H-w P D$

5: M-GDP + M-wPD

6: M-GDP + L-WPD

7: L-GDP + H-WPD

8: L-GDP + M-WPD

9: L-GDP + L-WPD

10: VL-wPD

11: VL-GDP

Source: PBL

GDP >

Figure A.2: Overview of the 11 different clusters in Europe 


\section{A.2 Description of the indicators and sub-indicators for Regional Quality of Living}

Indicators and sub-indicators were chosen which are important for people, individually or with their families, related to foreign companies that want to settle in a specific region, either for some time or permanently. After concerning several indicators applied in the Quality of Living Index (Mercer 2010), Liveability Index (EIU 2012) and OECD Better Life index data we selected for 25 sub-indicators aggregated to 9 indicators representing the Quality of Living.

$\boldsymbol{R Q I}$ 1. Governance Governance is an important factor for people when deciding to settle in a region. This was taken into account in all "quality of living" indices. The indicator Governance was calculated with the sub-indicators RQI 1.1 Government Effectiveness, $R Q I$ 1.2 Political Stability and Terror and RQI 1.3 Banks. Governance data were derived from the World Governance Indicators (Worldbank 2012), a recent study on regional variation in quality of government within the EU (Charron et al. 2012). Data on corruption were also taken into account, as well as EU regional statistics and perception data from the EU Urban Audit, Perception Survey (Eurostat 2015a). Data from the Global Peace Index were used (VoH 2012) for Political Stability and Terror. The scores for Banks resulted from a benchmark using OECD data on the soundness of banks taken from Sustainable Governance Indicators (OECD 2011) and the Standard and Poor's credit rating per country.

RQI 2. Purchasing Power and Employment The indicator RQI 2 Purchasing Power and Employment is the result of the average of three sub-indicators: $R Q I 2.1$ Housing Affordability, RQI 2.2 Employment and $R Q I 2.3$ Cost of Living. For the $R Q I 2.2$ Employment data for unemployment of people aged from 15 to 24 , and 20 to 65, were derived from Eurostat's regional labour market statistics. Price level indices with a correction for income per capita were used for the RQI 2.3 Cost of Living. The sub-indicator 2.1 Housing Affordability refers to the property price per square meter, divided by income per capita.

RQI 3. Social Environment When people decide whether or not they intend to settle in a certain region, Freedom, Safety in the personal environment and Social Cohesion are important factors, representing the Social Environment. RQI 3.1 Safety was calculated with the indicators $R Q I$ 3.1 Safety, RQI 3.2 Personal Freedom and $R Q I$ 3.3 Social Cohesion. Data for Safety were obtained from DG Regional Policy research (Charron et al. 2012) and the EU perception survey. The sub-indicator 3.2 Personal Freedom was constructed with country data from Sustainable Governance Indicators with a regional correction. Regional data on Voice and Accountability were derived from a recent study on regional variation in the quality of government in EU member states (DG Regional Policy 2010). The data for Social Cohesion were derived from the European Social Survey (ESS 2014) and Eurofound (2014).

$\boldsymbol{R Q I}$ 4. Health The indicator Health was calculated with four sub-indicators. $R Q I$ 4.1 Healthcare represents the average of 7 datasets representing qualitative and quantitative aspects of healthcare. $R Q I 4.3$ Life Expectancy includes life expectancy at birth and at the age of 65 , and healthy years at the age of 50. RQI 4.4 Environmental Quality was focussed on health effects as a consequence of environmental pollution. Objective data on air quality (particulate matter and ozone) and noise, as well as perception data were used for calculation of the score for Environmental Quality. Most of these data were derived from the Urban Audit data 'Key Cities', a database of 416 cities, and the European Environmental Agency. RQI 4.2 Food Quality and Safety is a country sub-indicator and was derived from the Global Food Security Index (EIU 2012).

$\boldsymbol{R Q I}$ 5. Education Education is an important settlement factor for both companies and potential residents. The qualitative aspects ( $R Q I 5.1)$ as well as the quantitative aspects (RQI 5.2) were considered. Quality standards and education opportunities (including higher education) are among the factors that people take into account when choosing to settle in a specific region. The data used for the sub-indicator 5.1 
Education Quality were derived from PISA (2012), university rankings and the EU Urban Audit (perception surveys). The 'Distance decay method' was applied for the sub-indicator 5.2 Education Quantity. Regions near to those with universities benefit from this.

RQI 6. Public Services Public Services are important to potential residents when deciding where to settle. This indicator includes information from the sub-indicators 6.1 Energy Security, RQI 6.2 Internet and RQI 6.3 Connectivity. Data for Energy Security were derived from the World Economic Forum where the use of renewable energy sources produces high scores. The data used for the RQI 6.2 Internet (availability and quality) were derived from the EU Urban Audit. The sub-indicator 6.3 Connectivity refers to potential accessibility of the region by road, rail, and air. In terms of connectivity inside the region, only data from the EU perception surveys were available.

$\boldsymbol{R Q I}$ 7. Recreation The presence of restaurants or cultural possibilities and recreational opportunities are factors that also determine the quality of the living environment. This indicator was calculated with data from the sub-indicators $R Q I$ 7.1 Culture and Restaurants and $R Q I$ 7.2 Recreation Possibilities. Regions near those with high ranking restaurants (e.g. with Michelin stars) benefit from this factor based on the Distance decay method. RQI 7.2 Recreation Possibilities was calculated with data from Urban Audit - Key cities, LUCAS and the Perception survey.

RQI 8. Natural Environment Although the Natural Environment and in particular climate cannot directly be influenced by policy measures, it is a factor that is taken into account when people choose to settle in a certain region. Three sub-indicators were used for this: $R Q I$ 8.1 Climate, $R Q I$ 8.2 Natural Hazards and $R Q I$ 8.3 Nature. Climate data on temperature and precipitation were taken from the EU Urban Audit. Regions with medium temperatures and precipitation levels generally scored best, as high and low levels are not comfortable to most people. The sub-indicator RQI 8.2 Natural Hazards refers to the aggregated exposure potential for 11 natural hazards, including floods, forest fires, droughts, earthquakes and tropical storms. The regions' integrated sensitivity and response capacity (ESPON 2013) were also taken into account for this indicator. $R Q I 8.3$ included land use and biodiversity data.

RQI 9. Housing Housing covers $R Q I 9.1$ Housing Quality which refers to the quality of both privately owned and rented housing and RQI 9.2 Housing Environment which is made up of several datasets, including the amount of green space and green/blue urban areas, as well as data from the EU perception survey with respect to satisfaction with the housing environment, such as public spaces and green. 
Table A.1: Additional information with respect to the data applied for the calculation of the Regional Quality of Life Index

\begin{tabular}{|c|c|c|c|}
\hline $\begin{array}{l}\text { Indicator/ Sub-indicators/datasets } \\
\text { of Regional Quality of Living }\end{array}$ & $\begin{array}{l}\text { Geographical } \\
\text { level }\end{array}$ & Source & $\begin{array}{l}\text { Reference } \\
\text { year }\end{array}$ \\
\hline \multicolumn{4}{|l|}{ RQI 1 Governance } \\
\hline \multicolumn{4}{|l|}{$\begin{array}{l}\text { RQI 1.1 Governance Effectiveness (regi- } \\
\text { onal correction for national data applied) }\end{array}$} \\
\hline Government Effectiveness & Country & Worldbank 2012 & 2011 \\
\hline Regulatory Quality & Country & Worldbank 2012 & 2011 \\
\hline Rule of Law: & NUTS2/NUTS1 & $\begin{array}{l}\text { Charron et al. } \\
2012\end{array}$ & 2009 \\
\hline Control of Corruption & NUTS2/NUTS1 & $\begin{array}{l}\text { Charron et al. } \\
2012\end{array}$ & 2009 \\
\hline Corruption & Country & TI 2012 & 2012 \\
\hline \multicolumn{4}{|l|}{ RQI 1.2 Political Stability and terror } \\
\hline Political Terror Scale & $\begin{array}{l}\text { Country } \\
\text { Country }\end{array}$ & VoH 2012 & 2011 \\
\hline $\begin{array}{l}\text { Political Stability and Absence of } \\
\text { Violence/Terrorism }\end{array}$ & Country & Worldbank 2012 & 2011 \\
\hline Physical Integrity Rights Index & Country & VoH 2012 & 2011 \\
\hline Political stability & Country & CIRI 2012 & 2011 \\
\hline \multicolumn{4}{|l|}{ RQI 1.3 Banks (Country indicator) } \\
\hline Standard \& Poor Country ratings & Country & S\&P 2014 & 2013 \\
\hline Soundness of banks & Country & OECD 2011 & 2011 \\
\hline \multicolumn{4}{|l|}{ RQI 2 Purchasing power and jobs } \\
\hline $\begin{array}{l}\text { Price owner-occupied housing } \\
\text { (relative to Disposable income) }\end{array}$ & NUTS2 (both) & $\begin{array}{l}\text { Eurostat 2015a } \\
\text { Eurostat } 2015 a\end{array}$ & 2009 \\
\hline $\begin{array}{l}\text { Price rented housing } \\
\text { (relative to Disposable income) }\end{array}$ & NUTS2 (both) & $\begin{array}{l}\text { Eurostat 2015a } \\
\text { Eurostat 2015a }\end{array}$ & 2009 \\
\hline \multicolumn{4}{|l|}{ RQI 2.2 Employment } \\
\hline Unemployment (15-24 year age group) & NUTS2 & Eurostat 2015a & 2012 \\
\hline Unemployment (20-65 year age group) & NUTS2 & Eurostat $2015 \mathrm{a}$ & 2012 \\
\hline \multicolumn{4}{|l|}{ RQI 2.3 Cost of living } \\
\hline Price goods & Country (Goods) & Eurostat 2015a & 2010 \\
\hline (relative to Disposable income) & NUTS2 (income) & Eurostat 2015a & \\
\hline Price fuel/alcohol & Country (Goods) & Eurostat $2015 \mathrm{a}$ & 2010 \\
\hline (relative to Disposable income) & NUTS2 (income) & Eurostat $2015 \mathrm{a}$ & \\
\hline \multicolumn{4}{|l|}{ RQI 3 Social environment } \\
\hline \multicolumn{4}{|l|}{$\begin{array}{l}\text { RQI 3.1 Safety (regional correction for } \\
\text { national data applied) }\end{array}$} \\
\hline Feel safe in this city? & Cities & Eurostat $2015 \mathrm{a}$ & 2009 \\
\hline Most people can be trusted? & Cities & Eurostat $2015 \mathrm{a}$ & 2009 \\
\hline Feel safe in this neighbourhood? & Cities & Eurostat $2015 \mathrm{a}$ & 2009 \\
\hline $\begin{array}{l}\text { Business costs of crime and violence } \\
\text { (Country data) }\end{array}$ & Country & Eurostat $2015 \mathrm{a}$ & 2011 \\
\hline $\begin{array}{l}\text { Reliability of police services } \\
\text { (Country data) }\end{array}$ & Country & Eurostat $2015 \mathrm{a}$ & 2011 \\
\hline Organised crime (Country data) & Country & Eurostat $2015 \mathrm{a}$ & 2011 \\
\hline \multicolumn{4}{|l|}{ RQI 3.2 Freedom (Country Indicator) } \\
\hline Civil Rights & Country & OECD 2011 & 2011 \\
\hline Access to Information & Country & OECD 2011 & 2011 \\
\hline Voice and accountability & Country & Worldbank 2012 & 2011 \\
\hline \multicolumn{4}{|l|}{$\begin{array}{l}\text { RQI 3.3 Social cohesion } \\
\text { (Country indicator) }\end{array}$} \\
\hline $\begin{array}{l}\text { Most of the time: people helpful or mostly } \\
\text { looking out for themselves }\end{array}$ & NUTS2 & ESS 2014 & 2011 \\
\hline $\begin{array}{l}\text { Important to help people and care for } \\
\text { others well-being }\end{array}$ & NUTS2 & ESS 2014 & 2011 \\
\hline $\begin{array}{l}\text { Important to be loyal to friends and } \\
\text { devote to people close }\end{array}$ & NUTS2 & ESS 2014 & 2011 \\
\hline
\end{tabular}




\begin{tabular}{llll}
\hline $\begin{array}{l}\text { Indicator/ Sub-indicators/datasets } \\
\text { of Regional Quality of Living }\end{array}$ & $\begin{array}{l}\text { Geographical } \\
\text { level }\end{array}$ & Source & $\begin{array}{l}\text { Reference } \\
\text { year }\end{array}$ \\
\hline $\begin{array}{l}\text { Participating in social activities of a club, } \\
\text { society or association }\end{array}$ & NUTS2 & Eurofound 2014 & 2011 \\
$\begin{array}{l}\text { How often did you do unpaid voluntary } \\
\text { work in the last 12 months? }\end{array}$ & NUTS2 & Eurofound 2014 & 2011 \\
\hline
\end{tabular}

\section{RQI 4 Health}

\section{RQI 4.1 Healthcare}

Infant mortality rate

Satisfied with hospitals?

Cancer death rate

Per capita government expenditure

on health

Satisfied with healthcare?

Satisfied with doctors?

Heart disease death rate

Per capita total expenditure on health at average exchange rate (USD)

RQI 4.2 Food quality and safety

Food quality and safety

RQI 4.3 Life expectancy

(double weight of NUTS2 data)

Life expectancy at given exact age

Life expectancy at birth

Life expectancy, Females at age 65

Life expectancy, Males at age 65

Number of years of healthy life expected

RQI 4.4 Environmental quality

Air pollution is a big problem here?

Noise is a big problem here?

This is a clean city?

Number of days ozone concentration

exceeds $120 \mu \mathrm{g} / \mathrm{m}^{3}$

Number of days particulate matter conc.

$\left(\mathrm{PM}_{1} 0\right)$ exceeds $50 \mu \mathrm{g} / \mathrm{m}^{3}$

Accumulated ozone concentration in excess

$70 \mu \mathrm{g} / \mathrm{m}^{3}$

Annual average concentration of $\mathrm{PM}_{1} 0$

RQI 5 Education

RQI 5.1 Education quality

(double weight of PISA)

Satisfied with schools?

Quality of University - best $20 \%$

in world $=5$ etc.

PISA score

Aged 15 to 64 qualified at tertiary level

(ISCED 5-6)

Number of foreign languages

RQI 5.2 Education Availability

(3x weight Universities)

Number of universities per region

(Distance decay calculation)

$\mathrm{N}$-international schools per region

(Distance decay calculation)

\section{RQI 6 Public services}

RQI 6.1 Energy security

Energy security and access

\section{RQI 6.2 Internet}

Satisfied with public internet access? Households with access to the Internet Households with broadband access Individuals who ordered goods or services over the Internet

Country
Cities
NUTS2
Country

Cities
Cities
NUTS2
Country

\section{Eurostat 2015a \\ Eurostat 2015a \\ Eurostat 2015a \\ WHO 2011 \\ 2009 \\ 2009 \\ 2010 \\ 2011 \\ Eurostat 2015a 2009 \\ Eurostat 2015a 2009 \\ Eurostat 2015a 2010 \\ WHO 2011}

Country

EIU 2012

2012

NUTS2

Country

Country

Country

NUTS2

Eurostat 2015a 2010

OECD 2012b 2012

OECD 2012b 2012

OECD 2012b 2012

Eurostat 2015a 2010

Cities

Cities

Cities

NUTS2

NUTS2

NUTS2

NUTS2

Eurostat 2015a

Eurostat 2015a

Eurostat 2015a

Eurostat 2015a

2009

2009

2009

2011

Eurostat 2015a

2011

Eurostat 2015a

2011

Eurostat 2015a

2011

Cities

Cities

Eurostat 2015a

2009

QS 2013

2012

Country

NUTS2

Country

NCIS 2012

2012

Eurostat 2015a

2008

2008

Eurostat 2015a 2009

Cities

QS 2013

2012

Cities

Wikipedia 2014

2014

Country

WEF 2013

2012

Cities

NUTS2

NUTS2

NUTS2
Eurostat 2015a

Eurostat 2015a

Eurostat 2015a

Eurostat 2015a
2012

2012

2012

2012 


\begin{tabular}{|c|c|c|c|}
\hline $\begin{array}{l}\text { Indicator/ Sub-indicators/datasets } \\
\text { of Regional Quality of Living }\end{array}$ & $\begin{array}{l}\text { Geographical } \\
\text { level }\end{array}$ & Source & $\begin{array}{l}\text { Reference } \\
\text { year }\end{array}$ \\
\hline \multicolumn{4}{|l|}{ RQI 6.3 Connectivity } \\
\hline Satisfied with public transport? & Cities & Eurostat $2015 \mathrm{a}$ & 2009 \\
\hline Rail accessibility & NUTS3 & ESPON 2011 & 2011 \\
\hline Road accessibility & NUTS3 & ESPON 2011 & 2011 \\
\hline Air accessibility & NUTS3 & ESPON 2011 & 2011 \\
\hline \multicolumn{4}{|l|}{ RQI 7 Recreation } \\
\hline \multicolumn{4}{|l|}{ RQI 7.1 Culture and Restaurants } \\
\hline $\begin{array}{l}\text { Michelin star restaurants } \\
\text { (Distance decay calculation) }\end{array}$ & Cities & Michelin 2013 & 2012 \\
\hline Satisfied with cultural facilities? & Cities & Eurostat 2015a & 2009 \\
\hline Satisfied with cinemas? & Cities & Eurostat $2015 \mathrm{a}$ & 2009 \\
\hline \multicolumn{4}{|l|}{ RQI 7.2 Recreation possibilities } \\
\hline Satisfied with sports facilities? & Cities & Eurostat 2015a & 2009 \\
\hline Area for recreational sports and leisure use & Cities & Eurostat $2015 \mathrm{a}$ & 2011 \\
\hline $\begin{array}{l}\text { Land area for recreational sports and } \\
\text { leisure (use/cap) }\end{array}$ & Cities & Eurostat $2015 \mathrm{a}$ & 2011 \\
\hline Length of bicycle network & Cities & Eurostat 2015a & 2011 \\
\hline Satisfied with outdoor recreation? & Cities & Eurostat $2015 \mathrm{a}$ & 2009 \\
\hline Recreation, leisure and sport & NUTS2 & Eurostat $2015 \mathrm{a}$ & 2009 \\
\hline \multicolumn{4}{|l|}{ RQI 8 Natural environment } \\
\hline Number of days of rain per year & NUTS2 & Eurostat 2015a & 2011 \\
\hline $\begin{array}{l}\text { Average number of hours of sunshine } \\
\text { per day }\end{array}$ & NUTS2 & Eurostat 2015a & 2011 \\
\hline Average temperature of warmest month & NUTS2 & Eurostat $2015 \mathrm{a}$ & 2011 \\
\hline Average temperature of coldest month & NUTS2 & Eurostat 2015a & 2011 \\
\hline Rainfall & NUTS2 & Eurostat $2015 \mathrm{a}$ & 2011 \\
\hline \multicolumn{4}{|l|}{ RQI 8.2 Natural hazards } \\
\hline Aggregated hazard exposure potential & NUTS2 & ESPON 2013 & 2010 \\
\hline Sensitivity and response & NUTS2 & ESPON 2013 & 2010 \\
\hline \multicolumn{4}{|l|}{ RQI 8.3 Nature } \\
\hline Recreation, leisure and sport & NUTS2 & Eurostat $2015 \mathrm{a}$ & 2009 \\
\hline Nature reserves & NUTS2 & Eurostat 2015a & 2009 \\
\hline Forestry & NUTS2 & Eurostat $2015 \mathrm{a}$ & 2009 \\
\hline Landscape Shannon Evenness Index & Country & Eurostat $2015 \mathrm{~b}$ & 2009 \\
\hline \multicolumn{4}{|l|}{ RQI 9 Housing } \\
\hline \multicolumn{4}{|l|}{ RQI 9.1 Housing quality } \\
\hline Average price per $\mathrm{m}^{2}-$ apartment & NUTS2 & Eurostat 2015a & 2009 \\
\hline Average price per $\mathrm{m}^{2}-$ house & NUTS2 & Eurostat $2015 \mathrm{a}$ & 2009 \\
\hline Rooms per person & Country & OECD 2012b & 2009 \\
\hline Dwellings with basic facilities & Country & OECD $2012 b$ & 2009 \\
\hline \multicolumn{4}{|l|}{ RQI 9.2 Housing environment } \\
\hline Satisfied with green space? & Cities & Eurostat 2015a & 2009 \\
\hline Satisfied to live in this city? & Cities & Eurostat $2015 \mathrm{a}$ & 2009 \\
\hline $\begin{array}{l}\text { In } 5 \text { years, it will be more pleasant } \\
\text { to live here? }\end{array}$ & Cities & Eurostat $2015 \mathrm{a}$ & 2009 \\
\hline Satisfied with public spaces? & Cities & Eurostat 2015a & 2009 \\
\hline $\begin{array}{l}\text { Green space (in } \mathrm{m}^{2} \text { ) to which the public has } \\
\text { access, per capita }\end{array}$ & Cities & Eurostat $2015 \mathrm{a}$ & 2009 \\
\hline Proportion of the area in green space & Cities & Eurostat $2015 \mathrm{a}$ & 2009 \\
\hline
\end{tabular}

Note: Indicator scores were calculated from average of sub-indicators unless otherwise mentioned. Sub-indicators were calculated from average of underlyingdata unless otherwise mentioned. 
A.3 Tables with RQI values of the European regions divided in 11 clusters

Table A.2: Regions with High GDP per capita

\begin{tabular}{|llcr|}
\hline Cluster 1 H-GDP + H-wPD & & \\
NUTS2 & NUTS2 name & $\begin{array}{c}\text { RQI } \\
\text { score }\end{array}$ & $\begin{array}{r}\text { RQI Indicator } \\
\text { rode }\end{array}$ \\
CH04 & Zürich & 7.82 & $5,6-9,7$ \\
NL00 & Amsterdam Great & 7.82 & $5,0-9,6$ \\
CH03 & Nordwestschweiz & 7.76 & $5,9-9,6$ \\
CH01 & Région lémanique & 7.74 & $5,0-9,9$ \\
NL33 & Zuid-Holland & 7.68 & $4,7-9,7$ \\
NO01 & Oslo og Akershus & 7.62 & $5,8-9,9$ \\
NL31 & Utrecht & 7.58 & $3,8-9,5$ \\
DE21 & Oberbayern & 7.54 & $5,2-8,9$ \\
BE21 & Prov. Antwerpen & 7.53 & $4,0-9,4$ \\
SE11 & Stockholm & 7.52 & $5,8-9,6$ \\
AT00 & Wien Great & 7.52 & $6,3-8,8$ \\
FR10 & île de France & 7.49 & $5,5-9,8$ \\
DK01 & Hovedstaden & 7.45 & $5,3-9,5$ \\
F11B & Helsinki-Uusimaa & 7.41 & $5,4-9,6$ \\
DE25 & Mittelfranken & 7.31 & $5,5-8,9$ \\
UK00 & London Great & 7.29 & $4,4-8,7$ \\
BE00 & Bruxelles great & 7.17 & $4,8-9,1$ \\
DE71 & Darmstadt & 7.10 & $4,8-8,7$ \\
DE60 & Hamburg & 7.00 & $4,0-8,7$ \\
DEA2 & Köln & 6.99 & $4,4-8,6$ \\
DE50 & Bremen & 6.91 & $3,9-8,6$ \\
DEA1 & Dusseldorf & 6.89 & $3,6-8,6$ \\
ES21 & País Vasco & 6.01 & $4,0-8,3$ \\
ITC4 & Lombardia & 5.94 & $4,5-7,1$ \\
\hline
\end{tabular}

\begin{tabular}{|c|c|c|c|}
\hline \multicolumn{4}{|c|}{ Cluster $2 \mathrm{H}-\mathrm{GDP}+\mathrm{M}-\mathrm{wPD}$} \\
\hline $\begin{array}{l}\text { NUTS2 } \\
\text { code }\end{array}$ & NUTS2 name & $\begin{array}{l}\text { RQI } \\
\text { score }\end{array}$ & $\begin{array}{r}\text { RQI Indicator } \\
\text { range }\end{array}$ \\
\hline NL41 & Noord-Brabant & 7.76 & $5,1-9,5$ \\
\hline $\mathrm{CHO2}$ & Espace Mittelland & 7.70 & $5,9-9,4$ \\
\hline Luoo & Luxembourg & 7.68 & $5,0-9,5$ \\
\hline NL11 & Groningen & 7.60 & $4,5-9,7$ \\
\hline NL42 & Limburg (NL) & 7.53 & $4,9-9,1$ \\
\hline SE23 & Västsverige & 7.51 & $5,2-9,5$ \\
\hline $\mathrm{CHO6}$ & Zentralschweiz & 7.49 & $5,2-9,4$ \\
\hline DE12 & Karlsruhe & 7.46 & $5,4-8,7$ \\
\hline NL21 & Overijssel & 7.42 & $4,9-9,4$ \\
\hline UKJ1 & Berkshire, Buckingh: & 7.37 & $4,7-9,3$ \\
\hline SE22 & Sydsverige & 7.36 & $4,9-9,5$ \\
\hline DK04 & Midtjylland & 7.33 & $5,3-9,7$ \\
\hline DE14 & Tübingen & 7.28 & $5,6-8,6$ \\
\hline AT32 & Salzburg & 7.12 & $4,9-9,0$ \\
\hline DE27 & Schwaben & 7.09 & $5,3-8,9$ \\
\hline AT34 & Vorarlberg & 7.02 & $4,7-8,6$ \\
\hline $\mathrm{CHO7}$ & Ticino & 6.99 & $4,8-9,4$ \\
\hline UKM5 & North Eastern Scotle & 6.98 & $5,8-8,5$ \\
\hline IEO2 & Southern and Easter & 6.97 & $4,8-9,0$ \\
\hline DE11 & Stuttgart & 6.95 & $5,1-8,6$ \\
\hline BE25 & Prov. West-Vlaande & 6.90 & $5,2-8,1$ \\
\hline ITH5 & Emilia-RomagNA & 5.80 & $4,7-7,1$ \\
\hline
\end{tabular}

\begin{tabular}{|c|c|c|c|}
\hline \multicolumn{4}{|c|}{ Cluster 3 H-GDP + L- wPD } \\
\hline NUTS2 & & RQI & RQI Indicato \\
\hline code & NUTS2 name & score & range \\
\hline SE12 & Östra Mellansverige & 7.62 & $5,1-9,6$ \\
\hline DK02 & Sjælland & 7.48 & $5,0-9,6$ \\
\hline NL34 & Zeeland & 7.44 & $5,0-9,2$ \\
\hline DKO3 & Syddanmark & 7.41 & $5,8-9,6$ \\
\hline SE33 & Övre Norrland & 7.31 & $5,3-9,4$ \\
\hline DE26 & Unterfranken & 7.26 & $5,6-8,9$ \\
\hline АТз3 & Tirol & 7.24 & $5,4-8,7$ \\
\hline DK05 & Nordjylland & 7.21 & $5,7-9,5$ \\
\hline $\mathrm{CHO5}$ & Ostschweiz & 7.14 & $4,9-9,4$ \\
\hline NO04 & Agder og Rogaland & 7.11 & $4,8-9,9$ \\
\hline AT31 & Oberösterreich & 7.10 & $5,7-8,6$ \\
\hline SE31 & Norra Mellansverige & 7.09 & $3,8-9,4$ \\
\hline NO05 & Vestlandet & 7.03 & $3,8-9,9$ \\
\hline NO06 & Trøndelag & 7.02 & $4,3-9,9$ \\
\hline DE23 & Oberpfalz & 7.01 & $5,2-8,9$ \\
\hline NO03 & Sør- $\varnothing$ stlandet & 6.34 & $1,9-9,9$ \\
\hline ITH2 & Provincia Autonoma I & 6.26 & $5,0-7,5$ \\
\hline ITH1 & Provincia Autonoma a & 6.21 & $4,9-7,3$ \\
\hline ITC2 & Valle d'Aosta/Vallée c & 5.86 & $5,0-6,8$ \\
\hline
\end{tabular}


Table A.3: Regions with Moderate GDP

\begin{tabular}{|lllr|}
\hline Cluster 4 M-GDP + H-wPD & & \\
NUTS2 & & RQI & RQI Indicator \\
code & NUTS2 name & score & range \\
UKJ2 & Surrey, East and We: & 7.53 & $5,9-9,1$ \\
FR71 & Rhône-Alpes & 7.37 & $5,3-9,0$ \\
DE00 & Berlin Great & 7.33 & $6,0-8,6$ \\
UKK1 & Gloucestershire, Wil & 7.11 & $4,6-8,5$ \\
UKF2 & Leicestershire, Rutla & 7.08 & $4,5-8,6$ \\
UKF1 & Derbyshire and Nott & 7.07 & $4,5-8,6$ \\
DEA3 & Münster & 6.99 & $4,6-8,6$ \\
DEA5 & Arnsberg & 6.90 & $4,5-8,6$ \\
UKM3 & South Western Scotl & 6.87 & $4,8-8,5$ \\
UKD3 & Greater Manchester & 6.74 & $3,4-8,2$ \\
UKC2 & Northumberland anc & 6.70 & $4,8-8,3$ \\
DED5 & Chemnitz & 6.65 & $4,8-8,7$ \\
UKG3 & West Midlands & 6.65 & $3,9-8,3$ \\
UKD7 & Merseyside (NUTS 21 & 6.64 & $4,5-8,2$ \\
UKE3 & South Yorkshire & 6.57 & $3,8-8,2$ \\
UKE4 & West Yorkshire & 6.55 & $2,2-8,2$ \\
FR30 & Nord - Pas-de-Calais & 6.51 & $4,8-7,9$ \\
FR82 & Provence-Alpes-Côte & 6.31 & $4,7-7,5$ \\
ES51 & Cataluña & 6.30 & $4,3-8,5$ \\
ES22 & Comunidad Foral de & 6.26 & $4,1-7,9$ \\
CZ00 & Praha Great & 6.10 & $5,0-7,3$ \\
ES30 & Comunidad de Madr & 6.10 & $4,2-7,5$ \\
ES24 & Aragón & 5.91 & $4,1-7,7$ \\
ES12 & Principado de Asturi & 5.89 & $4,1-8,3$ \\
ES52 & Comunidad Valencia & 5.87 & $3,4-7,4$ \\
ES53 & Illes Balears & 5.85 & $3,7-7,4$ \\
ITC1 & Piemonte & 5.67 & $4,8-6,7$ \\
PT17 & Lisboa & 5.48 & $3,8-7,0$ \\
IT14 & Lazio & 5.45 & $4,4-6,8$ \\
EL30 & Attiki & 4.44 & $3,3-6,4$ \\
\hline & & & \\
\hline & & &
\end{tabular}

\begin{tabular}{|c|c|c|c|}
\hline \multicolumn{4}{|c|}{ Cluster 5 M-GDP + M-wPD } \\
\hline $\begin{array}{l}\text { NUTS2 } \\
\text { code }\end{array}$ & NUTS2 name & $\begin{array}{l}\text { RQI } \\
\text { score }\end{array}$ & RQI Indicator \\
\hline NL22 & Gelderland & 7.67 & $4,8-9,4$ \\
\hline BE23 & Prov. Oost-Vlaander & 7.62 & $5,3-8,8$ \\
\hline UKJ3 & Hampshire and Isle , & 7.37 & $5,8-8,7$ \\
\hline DE92 & Hannover & 7.29 & $5,8-8,7$ \\
\hline UKJ4 & Kent & 7.27 & $5,8-8,7$ \\
\hline DEFO & Schleswig-Holstein & 7.27 & $6,2-8,8$ \\
\hline BE22 & Prov. Limburg (BE) & 7.24 & $5,2-8,2$ \\
\hline DE13 & Freiburg & 7.20 & $5,2-8,6$ \\
\hline UKH1 & East Anglia & 7.19 & $5,4-8,6$ \\
\hline DEA4 & Detmold & 7.13 & $5,5-8,6$ \\
\hline FR42 & Alsace & 7.12 & $5,5-8,0$ \\
\hline DE91 & Braunschweig & 7.07 & $5,5-8,7$ \\
\hline UKG1 & Herefordshire, Worc & 7.07 & $5,1-8,8$ \\
\hline UKL2 & East Wales & 7.03 & $4,7-8,4$ \\
\hline FR61 & Aquitaine & 7.03 & $5,1-8,4$ \\
\hline UKE2 & North Yorkshire & 7.02 & $5,1-8,2$ \\
\hline AT22 & Steiermark & 7.01 & $5,8-8,4$ \\
\hline FR62 & Midi-Pyrénées & 6.99 & $5,4-8,5$ \\
\hline DEB3 & Rheinhessen-Pfalz & 6.98 & $5,0-8,8$ \\
\hline UKK2 & Dorset and Somerse & 6.96 & $5,0-8,1$ \\
\hline UKM2 & Eastern Scotland & 6.94 & $4,9-8,5-1-2$ \\
\hline FR24 & Centre (FR) & 6.92 & $5,1-8,0$ \\
\hline DED2 & Dresden & 6.92 & $5,9-8,7$ \\
\hline FR51 & Pays de la Loire & 6.91 & $4,6-8,5$ \\
\hline FR41 & Lorraine & 6.89 & $5,6-8,0$ \\
\hline DED4 & Leipzig & 6.89 & $4,4-8,7$ \\
\hline DECO & Saarland & 6.84 & $4,6-8,6$ \\
\hline DEEO & Sachsen-Anhalt & 6.83 & $4,4-8,5$ \\
\hline DE73 & Kassel & 6.83 & $4,7-8,7$ \\
\hline FR23 & Haute-Normandie & 6.82 & $5,2-8,2$ \\
\hline FR72 & Auvergne & 6.77 & $4,8-8,0$ \\
\hline UKD6 & Cheshire & 6.73 & $3,7-8,2$ \\
\hline FR21 & Champagne-Ardenn & 6.73 & $4,9-7,9$ \\
\hline UKG2 & Shropshire and Staff & 6.72 & $4,1-8,3$ \\
\hline UKE1 & East Yorkshire and $\mathrm{A}$ & 6.66 & $5,3-8,2$ \\
\hline ВЕ33 & Prov. Liège & 6.63 & $5,3-7,6$ \\
\hline UKD4 & Lancashire & 6.60 & $3,6-8,2$ \\
\hline UKNO & Northern Ireland (U) & 6.52 & $5,1-8,0$ \\
\hline UKK4 & Devon & 6.50 & $5,0-8,1$ \\
\hline FR81 & Languedoc-Roussillc & 6.45 & $5,1-7,6$ \\
\hline BE32 & Prov. HaiNAut & 6.43 & $4,9-7,6$ \\
\hline ES11 & Galicia & 6.07 & $4,4-8,4$ \\
\hline ITH4 & Friuli-Venezia Giulia & 5.98 & $5,0-7,4$ \\
\hline ES23 & La Rioja & 5.98 & $3,9-7,8$ \\
\hline ES13 & Cantabria & 5.90 & $4,1-8,6$ \\
\hline SLO2 & ZahodNA Slovenija & 5.85 & $3,7-6,9$ \\
\hline ITH3 & Veneto & 5.83 & $4,7-7,2$ \\
\hline ES41 & Castilla y León & 5.80 & $3,9-7,8$ \\
\hline SK01 & Bratislavský kraj & 5.51 & $3,4-7,4$ \\
\hline ITC3 & Liguria & 5.48 & $3,8-7,3$ \\
\hline |TI1 & ToscaNA & 5.31 & $3,4-6,8$ \\
\hline CYOO & Kypros & 5.17 & $2,1-7,2$ \\
\hline
\end{tabular}

\begin{tabular}{|lrrr|}
\hline Cluster 6 M-GDP + L- wPD & & \\
NUTS2 & RQI & RQI Indicator \\
code & NUTS2 name & $\begin{array}{r}\text { RQI } \\
\text { score }\end{array}$ & range \\
NL13 & Drenthe & 7.53 & $5,3-9,7$ \\
NL12 & Friesland (NL) & 7.36 & $4,8-9,7$ \\
DEB2 & Trier & 7.20 & $5,2-8,8$ \\
DE24 & Oberfranken & 7.20 & $5,5-8,9$ \\
F11C & Etala Suomi & 7.16 & $4,3-9,6$ \\
DE93 & Lüneburg & 7.15 & $5,0-8,7$ \\
FR22 & Picardie & 7.06 & $5,5-8,1$ \\
DEB1 & Koblenz & 7.04 & $4,9-8,8$ \\
DE22 & Niederbayern & 7.03 & $5,1-8,9$ \\
F11D & Pohjois-JA Ita & 6.99 & $4,6-9,6$ \\
F19 & Länsi-Suomi & 6.99 & $4,5-9,6$ \\
DE72 & Gießen & 6.97 & $5,0-8,7$ \\
DE94 & Weser-Ems & 6.93 & $4,9-8,7$ \\
FR63 & Limousin & 6.92 & $4,6-8,4$ \\
FR43 & Franche-Comté & 6.90 & $5,4-8,1$ \\
DEG0 & Thüringen & 6.90 & $4,7-8,8$ \\
FR53 & Poitou-Charentes & 6.90 & $4,4-8,5$ \\
FR52 & Bretagne & 6.88 & $4,7-8,4$ \\
DE80 & Mecklenburg-Vorpon & 6.87 & $4,1-8,8$ \\
AT21 & Kärnten & 6.84 & $4,5-8,7$ \\
FR25 & Basse-Normandie & 6.75 & $4,7-8,2$ \\
FR26 & Bourgogne & 6.70 & $4,7-8,0$ \\
BE35 & Prov. NAmur & 6.65 & $5,1-7,6$ \\
UKD1 & Cumbria & 6.62 & $4,8-8,2$ \\
FR83 & Corse & 6.44 & $4,1-7,7$ \\
IT12 & Umbria & 5.55 & $3,7-7,1$ \\
IT13 & Marche & 5.39 & $3,6-7,1$ \\
ITF1 & Abruzzo & 4.54 & $2,2-6,3$ \\
ITF2 & Molise & 4.46 & $2,2-6,5$ \\
\hline
\end{tabular}

Table A.4: Regions with Low GDP

\begin{tabular}{|llrr|}
\hline Cluster 7 L-GDP + H-wPD & & \\
NUTS2 & & RQI & RQI Indicator \\
code & NUTS2 name & score & range \\
PL12 & Mazowieckie & 5.64 & $4,0-7,4$ \\
PT11 & Norte & 5.42 & $3,6-7,3$ \\
PL11 & Lódzkie & 5.39 & $3,3-7,0$ \\
MT00 & Malta & 5.37 & $2,7-7,6$ \\
PL22 & Slaskie & 5.24 & $3,3-7,2$ \\
ES61 & Andalucía & 5.18 & $2,7-6,9$ \\
HU10 & Közép-Magyarország & 5.04 & $3,4-6,5$ \\
HR01 & SjeverozapadNA Hrv & 4.87 & $3,4-7,4$ \\
RO32 & Bucuresti - Ilfov & 4.33 & $2,1-8,9$ \\
EL12 & Kentriki Makedonia & 4.19 & $2,2-6,4$ \\
ITF3 & Campania & 4.16 & $2,0-6,2$ \\
BG41 & Yugozapaden & 4.01 & $1,9-7,1$ \\
\hline
\end{tabular}

\begin{tabular}{|c|c|c|c|}
\hline \multicolumn{4}{|c|}{ Cluster $8 \mathrm{~L}-\mathrm{GDP}+\mathrm{M}$-wPD } \\
\hline $\begin{array}{l}\text { NUTS2 } \\
\text { code }\end{array}$ & NUTS2 name & $\begin{array}{l}\text { RQI } \\
\text { score }\end{array}$ & $\begin{array}{r}\text { RQI Indicator } \\
\text { range }\end{array}$ \\
\hline UKL1 & West Wales and The & 6.85 & $5,0-8,3$ \\
\hline UKC1 & Tees Valley and Durl & 6.58 & $4,1-8,3$ \\
\hline CZO6 & Jihovýchod & 5.58 & $4,3-7,0$ \\
\hline EEOO & Eesti & 5.53 & $2,9-7,0$ \\
\hline ES62 & Región de Murcia & 5.52 & $3,6-7,9$ \\
\hline PL41 & Wielkopolskie & 5.51 & $3,9-7,3$ \\
\hline PL42 & Zachodniopomorski & 5.49 & $3,8-7,2$ \\
\hline CZO8 & Moravskoslezsko & 5.45 & $4,0-7,1$ \\
\hline PL51 & Dolnoslaskie & 5.44 & $3,4-7,3$ \\
\hline PL34 & Podlaskie & 5.33 & $3,2-7,5$ \\
\hline PL63 & Pomorskie & 5.23 & $3,1-7,0$ \\
\hline PL61 & Kujawsko-Pomorskif & 5.16 & $3,0-6,9$ \\
\hline PL21 & Malopolskie & 5.16 & $3,8-6,1$ \\
\hline LVOO & Latvija & 4.72 & $3,3-7,6$ \\
\hline LTOO & Lithuania & 4.67 & $2,7-6,9$ \\
\hline EL43 & Kriti & 4.59 & $3,4-6,8$ \\
\hline ITG1 & Sicilia & 4.25 & $2,1-6,4$ \\
\hline EL23 & Dytiki Ellada & 4.25 & $1,9-6,5$ \\
\hline ITF4 & Puglia & 4.22 & $1,7-6,6$ \\
\hline EL14 & Thessalia & 4.20 & $2,1-6,4$ \\
\hline RO42 & Vest & 3.96 & $2,0-7,1$ \\
\hline
\end{tabular}

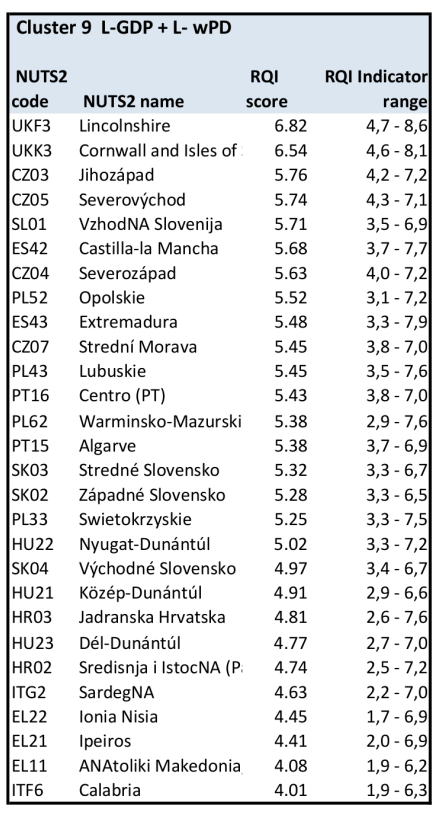


Table A.5: Regions with very low GDP or Population density

\begin{tabular}{|llrr|}
\hline Cluster 10 VL-wPD & & \\
NUTS2 & & RQI & RQI Indicator \\
code & NUTS2 name & $\begin{array}{r}\text { score } \\
\text { sange }\end{array}$ \\
AT11 & Burgenland (AT) & 7.45 & $5,4-9,2$ \\
SE21 & Småland med öarNA & 7.37 & $5,1-9,5$ \\
F120 & Áland & 7.37 & $4,6-9,6$ \\
SE32 & Mellersta Norrland & 7.00 & $3,6-9,4$ \\
UKM6 & Highlands and IIland & 6.79 & $4,7-8,5$ \\
NO07 & Nord-Norge & 6.74 & $3,4-9,9$ \\
BE34 & Prov. Luxembourg (E & 6.63 & $5,0-7,6$ \\
IE01 & Border, Midland and & 6.41 & $4,4-9,0$ \\
NO02 & Hedmark og Opplani & 6.23 & $1,6-9,9$ \\
PT18 & Alentejo & 5.31 & $2,8-7,8$ \\
EL42 & Notio Aigaio & 4.47 & $2,2-6,9$ \\
EL41 & Voreio Aigaio & 4.43 & $2,3-6,9$ \\
EL25 & Peloponnisos & 4.32 & $2,0-6,6$ \\
EL24 & Sterea Ellada & 4.26 & $2,0-6,5$ \\
ITF5 & Basilicata & 4.24 & $1,8-6,4$ \\
EL13 & Dytiki Makedonia & 4.00 & $1,8-6,5$ \\
\hline
\end{tabular}

\begin{tabular}{|c|c|c|c|}
\hline \multicolumn{4}{|c|}{ Cluster 11 VL-GDP } \\
\hline $\begin{array}{l}\text { NUTS2 } \\
\text { code }\end{array}$ & NUTS2 name & $\begin{array}{l}\text { RQI } \\
\text { score }\end{array}$ & $\begin{array}{r}\text { RQI Indicator } \\
\text { range }\end{array}$ \\
\hline PL32 & Podkarpackie & 5.35 & $3,0-7,8$ \\
\hline PL31 & Lubelskie & 5.10 & $3,1-7,3$ \\
\hline HU33 & Dél-Alföld & 4.69 & $2,8-7,3$ \\
\hline RO22 & Sud-Est & 4.68 & $2,0-8,3$ \\
\hline HU31 & Észak-Magyarország & 4.58 & $2,7-6,9$ \\
\hline HU32 & Észak-Alföld & 4.50 & $2,6-6,7$ \\
\hline RO41 & Sud-Vest Oltenia & 4.35 & $1,9-7,9$ \\
\hline RO11 & Nord-Vest & 4.31 & $2,1-7,1$ \\
\hline RO12 & Centru & 4.21 & $2,1-6,8$ \\
\hline RO31 & Sud - Muntenia & 4.00 & $2,0-7,4$ \\
\hline RO21 & Nord-Est & 3.94 & $1,7-7,2$ \\
\hline BG33 & Severoiztochen & 3.63 & $1,8-7,3$ \\
\hline BG42 & Yuzhen tsentralen & 3.53 & $1,5-6,7$ \\
\hline BG34 & Yugoiztochen & 3.43 & $1,8-6,2$ \\
\hline BG32 & Severen tsentralen & 3.41 & $1,4-7,2$ \\
\hline BG31 & Severozapaden & 3.34 & $1,3-7,0$ \\
\hline
\end{tabular}

